Portland State University

PDXScholar

1974

\title{
An Attitudinal Study of Secondary School Teachers Toward School Social Workers
}

\author{
Raymond Merritt \\ Portland State University \\ Dwayne McNannay \\ Portland State University
}

Follow this and additional works at: https://pdxscholar.library.pdx.edu/open_access_etds

Part of the Social Work Commons

Let us know how access to this document benefits you.

\section{Recommended Citation}

Merritt, Raymond and McNannay, Dwayne, "An Attitudinal Study of Secondary School Teachers Toward School Social Workers" (1974). Dissertations and Theses. Paper 1738.

https://doi.org/10.15760/etd.1737

This Thesis is brought to you for free and open access. It has been accepted for inclusion in Dissertations and Theses by an authorized administrator of PDXScholar. Please contact us if we can make this document more accessible: pdxscholar@pdx.edu. 
AN ATTITUDINAL STUDY OF SECONDARY SCHOOL TEACHERS

TOWARD SCHOOL SOCIAL WORKERS

by

RAYMOND MERRITT

DWAYNE MCNANNAY

A report submitted in partial fulfillment of the requirements for the degree of

MASTER OF

SOCIAL WORK

Portland State University 1973 
TABLE OF CONTENTS

Page

CHAPTER .

I INTRODUCTIION 1

II METHODOLOGY - 4

Formulation of a Nu11 Hypothesis 4

Definition of Semantic Differential 5

Selecting the Concepts for the -Questionnaire

Selecting the Adjective Pairs

$\begin{array}{ll}\text { Population and Sampling Procedure } & 7\end{array}$

Coding and Statistical Computation 8

Chapter Notes 9

$\begin{array}{ll} & 10\end{array}$

$\begin{array}{llr}\text { IV CONCLUSIONS } & 28\end{array}$

$\begin{array}{ll}\text { BIBLIOGRAPHY } & 31\end{array}$

APPENDIX 


\section{CHAPTER I}

$\because$

\section{INTRODUCTION}

John Adams is one of fourteen public high schools in the City of Portland. It serves approximately 1,200 students and employs a teaching staff of approximately one hundred certified teachers. In addition, ancillary services include school social workers employed by the school district and a unit of graduate students from the School of Social Work, Portland State University. In this respect John

- Adams is somewhat unique, as other high schools in the district occupy the position of having to draw from a centralized undermanned pool of social workers at best or to function without such services at any meaningful level. From a time perspective, Adams has enjoyed a position of having as much as 224 man hours per week in available social work services. (1971-72 school year)

However, the availability of adequate resources does not by itself insure that appropirate levels of service will be maintained or that day to day operating procedures will function harmoniously. Education is the primary function of the public school system and while ancillary services, including school social workers, are desirable, they do in [act, occupy a secondary priority within the total system.

$\Lambda$ s individuals in a complementary service, it appears prudent to determine the manner in which individuals who are engaged in the primary function of the institutions, teachers, view those engaged 
in the complementary service. The reality of the situation speaks to the fact that students who may be in need of assistance from a school social worker, are in the majority of cases first identified by the teacher. It is the teacher who has daily contact with the student, it is the teacher who will first become aware of changes in the student's behavior, it is the teacher who students of ten confide personal or family difficulties, and it is the teacher who will first be cognizant of the student's educational achievement falling below capacity. Therefore, this person is pivotal in insuring that students in need of school social work services obtain them. How does this pivotal person perceive the school social worker?

Numerous conversations with teachers revealed a wide divergence of opinions regarding school social workers, or at least we interpreted them as such. One group apparently viewed social workers as "do-gooders" whose primary responsibility involves delivering turkeys on Thanksgiving, according :o one teacher. Others painted the portrait of "excuse makers." As one șpokesman said, "No matter what the problem or type of behavior, you can count on social workers to explain it away by shifting responsibility to others."

Others viewed school social workers in a more positive light, but when attempts were made to define roles wide divergencies of opinion surfaced. Some teachers viewed social workers as being primarily responsible for truants and troublemakers regardless of the individual's situation. Others saw the school social worker as a junior psychiatrist who could be utilized before a problem becomes 
too serious. The list of possible functions, from the teachers' perspective, seemed to be infinite.

And finally we found still another group who were unaware that social workers existed within the same institution. They possessed neither positive nor negative feelings, but were simply unaware of our existence.

Having encountered such statements in our practice as school social workers, we felt that it would be useful to gain some understanding of currently held attitudes by teachers towards social workers. With teachers being the pivotal person in the referral process in schools, these attitudes could in fact influence whether or not assistance - was offered to students in need. In fact, the possibility exists that pre-existing attitudes may determine the outcome of a referral prior to that referral taking place.

A review of the existing literature, including the Erich scanning mechanism, reveals that no previous research has concerned itself with this type of study. Thus, we felt that such an undertaking could prove beneficial to all involved, including teachers, school social workers and most importantly, the student. 
CHAPTER II

METHODOLOGY

This chapter will include methods employed for testing the null hypothesis and means of gathering statistical data for this study. The study was designed out of apparent difficulties that have arisen between teachers, counselors, administrators and social workers in the administration of casework services. The cause of these differences has been identified in some instances and includes difficulties in the referral procedure, differences in expectations and differences in role perceptions.

The chapter will be broken down into the following sections: the formulation of a null hypothesis, definition of semantic differential; population and sampling procedures; coding and statistical computation. Decisions were made by unanimous vote of the researchers involved and with consultation of the faculty advisor.

\section{THE FORMULATION OF A NULL HYPOTHESIS}

The formulation of a hypothesis came from considerable discussion of the researchers and faculty advisor. It was decided that we have two main null hypotheses.

A. Teachers at John Adams Iligh School see social workers as effective in a school setting. 
B. Teachers at John Adams High School are aware of the functions of school social workers in a public school setting.

The basis of our questionnaire and the statistical treatment of responses have been directed towards testing these two null hypotheses.

\section{II. ' DEFINITION OF SEMANTIC DIFFERENTIAI,}

It was decided by the researchers to use the statistical method of Semantic Differential for our testing. This particular measurement is described in the book The Measurement of Meaning by Osgood, Suci, and Tannenbaum.

The semantic differential is essentially a combination of controlled association and scaling procedures. We provide the subject with a concept to be differentiated and set of bipolar adjectival scales against which to do it, his only task being to indicate, for each item (pairing a concept with a scale), the direction of his association and its intensity on a seven-step scale. The crux of the method, of course, lies in selecting the sample of descriptive polar terms. ${ }^{1}$

\section{Selecting the Concepts for the Questionnaire}

The researchers and the faculty advisor selected concepts that they believed important in the area of school social work. The rescarchers picked seventeen concepts that were enclosed by placing all of them in a hat and then drawing one at a time. This drawing wass clone to avoid biases on the testers' part. The concepts drawn in order were:

1. Counseling

2. Group Work

3. Teachers

4. Truancy 
5. Educational Counseling

6. Welfare Families

7. Community Organization

8. Referring

9. Minority Students

10. School Social Work

11. Teacher

12. Employment Counseling

13. Consulting

14. Family Counseling

15. Research

16. Self

17. Casework

Selecting the Adjective Pairs

They were selected by a high factor analysis score taken from the book The Meaning of Measurement.

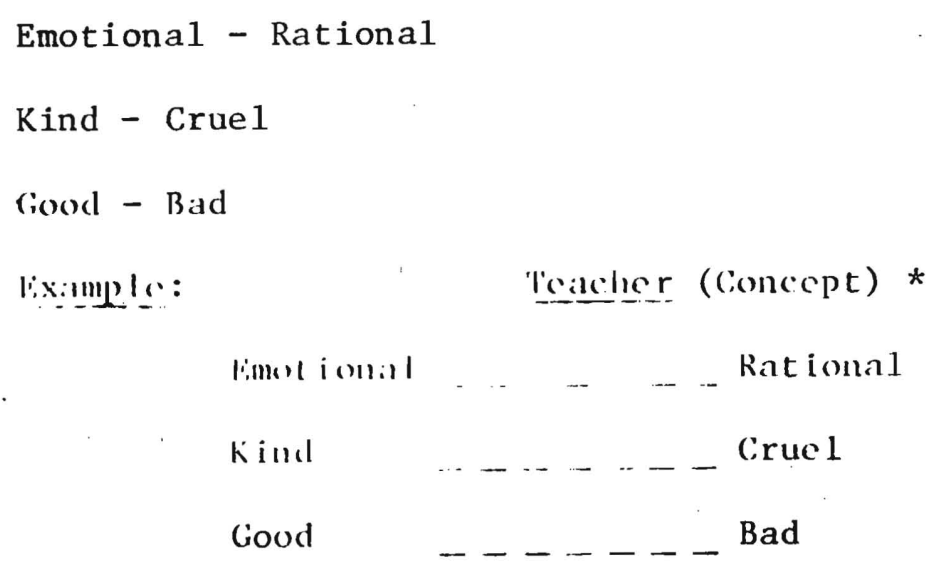

* See Sample Questionnaire in Appendix 
The adjective pairs were set up on a flip-flop basis to avoid lining up all positive pairs against all negative pairs. From the technique in the example we have produced three definitions of the concept "teacher."

Each semantic scale, defined by a pair of polar (oppositein-meaning) adjectives, is assumed to represent a straight line function that passes through the origin of this space, and a sample of such scales then represents a multidimensional space. The logical tool to uncover these dimensions is factor analysis. ${ }^{2}$

\section{POPULATION AND SAMPLING PROCEDURE}

The population of the study was divided up into three categories from John Adams High School in Portland. They were:
A. Certified teachers (at least one of teaching at John Adams)
B. Administration
C. Counseling Department

It was believed that if we could get a wide range of attitude responses that it would be significant for the study.

\section{Sampling Procedure}

From the previously mentioned categories we picked thirty-four teachers, five administrators and four counselors. This was done by the means of a stratified sample. A memo was directed to these three areas at John Adams High School stating that researchers would be roming around to ask their participation in completing a questionnaire regarding, school social work. The plan was to make personal contact with those selected in order to get a more responsive and reliable questionnaire return. Even with the preliminary memo, the researchers experienced hostility among those chosen for the study. 
A. Collection of data. Questionnaires were delivered personally or put in their mailbox at John Adams when personal contact was not possible. Two weeks was allowed for the completion and return of the questionnaire.

B. Returns. Not all questionnaires were returned. Out of the forty-six questionnaires handed out, twenty-six were returned to the researchers. Fifteen teachers returned their questionnaires and all questionnaires were received from the administration and counseling departments.

C. Attached to the questionnaire was a demographical sheet, developed to obtain information in the areas of (1) sex, (2) age, (3) years teaching, (4) years at John Adams, (5) marital status, (6) ethnic background, (7) department at John Adams and (7) type of degree.

This background information will be most helpful in determining a basis for identifying faculty views and attitudes towards school social workers.

\section{CODING AND STATISTICAL COMPUTATION}

A coding procedure was used so that the data collected could be more easily analyzed. With the assistance of Dr. Deane Clarkson, the researchers developed a method of numerical coding which included the demographical sheet and the seventeen conceptual responses. These identifying numbers were put down on a large computor printout shect, then the data was punched on data cards. Only the means and standard deviation of each adjective pair of each concept were tutilized in the analysis of the data. lowever, other statistical measurements were computed, such as analysis of variance and factor analysis. But, due to shortness of time and the large amount of data, the results of these measurements are not included in this study. Consequently, the null liypotheses cannot be proven or disproven, but indications can be derived through the analysis of the means and standard deviation. 
CHAPTER NOTES

1. Charles E. Osgood, George J. Suci and Percy H. Tannerbaum. The Measurement of Meaning. Illinois, University of Illinois, 1957.

2. Ibid. 
CHAPTER III

\section{SUMMARY OF DATA}

The respondents to the questionnaire.produced the following profile from the demographic information. Forty-six questionnaires were distributed and twenty-six were returned. of these, twenty are males and six are females. Six are between the ages of twenty-six to thirty, seven are between the ages of thirty-one to thirty-five, and thirteen are over thirty-five. The marital status of the twenty-six is as follows: four are single, nineteen are married, one is divorced, and two are separated. Twenty-four indicated a non-minority background and two are black. Tenure at John Adams among the respondents is as follows: nine are in their first year, seven are in their second year, nine are in their third year and one is in his fourth year. Twenty have utilized the services of a school social worker in their capacity as a teacher, five have not, and one failed to respond to this question.

The following tables demonstrate the respondents'cumulative responses to each concept. Each pair of adjectives used to measure the respondent's attitude towards the concept, has been computed to show the mean scores between the range of zero to seven. The right hand column is the computation of the standard deviation of responses for each set of adjectives. 


\section{SELF}

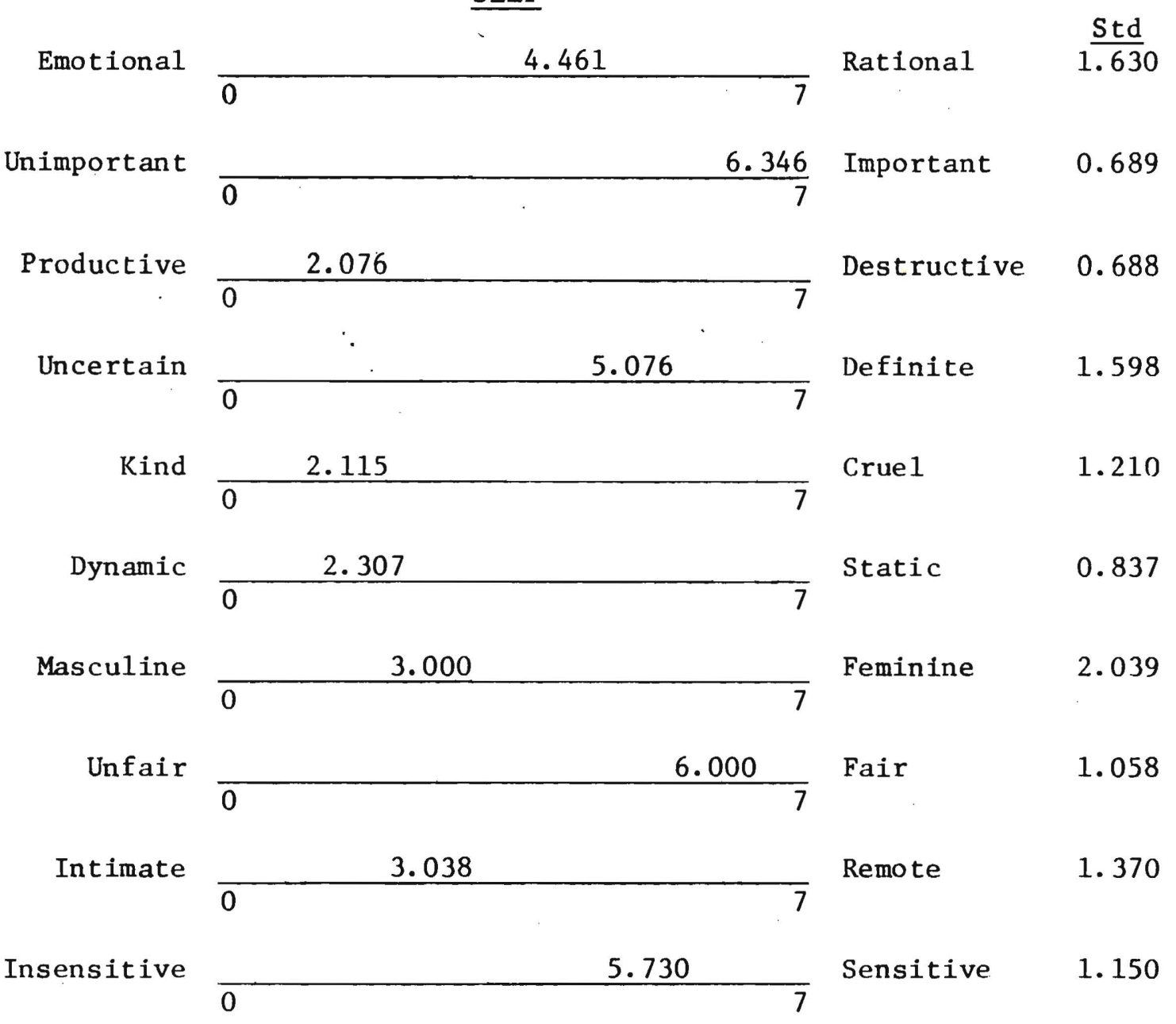

Utilizing the concept "self" as a primary anchor, the respondents' attitudes indicate a positive self image. They see themselves as being important, productive, and dynamic individuals. The scores further reveal that these teachers see themselves as being extremely fair and with a high degree of sensitivity. While they lean towards being definite and rational, these attributes do not occupy the puition of extreme significance in their total make-up. The masculine-feminine mean of 3.000 and standard deviation of 2.039 merely indicate the compo-sition of the sample. 
TEACHER

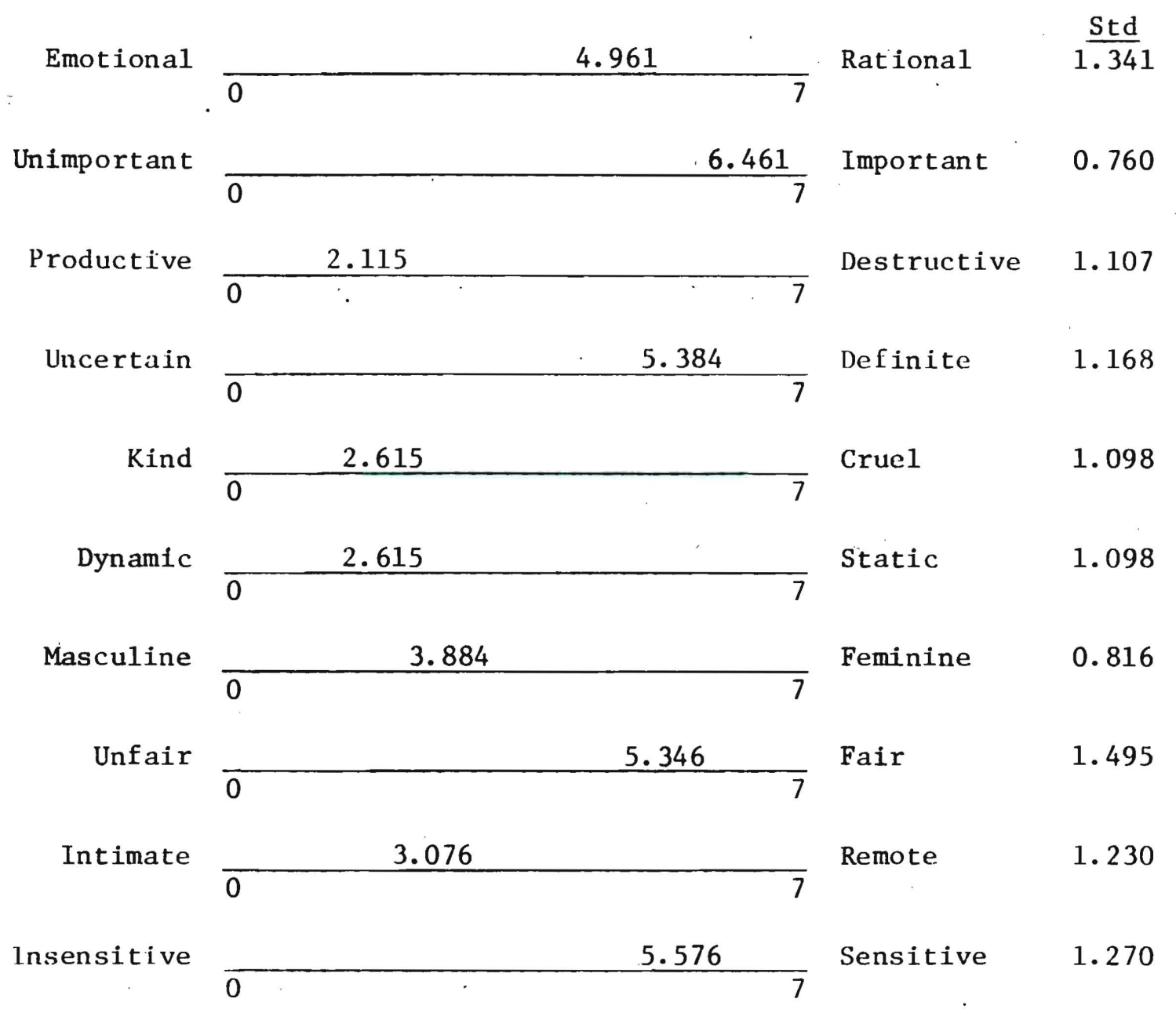

As teachers, the respondents attach extreme significance to their profession as the 6.461 mean and standard deviation of 0.760 demonstrate. However, in moving from "self" to "teacher" the respondents move towards the negative adjectives of destructive, static, and insensitive although the amount in each case in negligible. This may indicate some frustration in their roles as teachers or a feeling that they are unable, for some reason, to be themselves. 
SCHOOL SOCIAL WORKER

Emotional

Unimportant

Productive

$\frac{2.57}{0}$

Uncertain

$\overline{0}$

Kind

$\frac{2.38}{0}$

Dynamic

0

Masculine

0

Unfair

0

Intimate

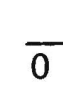

Insensitive

(1)

0
5.115

5.692

573

4.653

4.653

Definite

Crue1

1.022

7

3.115

3.576

Feminine

1.026

1.172

Fair

5.576

3.115

Remote

1.531

0

5.692

Sensitive

1. 319

The concept "school social worker" rated primarily positive responses, but certain comparisons are noteworthy. The concept is viewed as important, but not as important as "teachers." However, "school social worker" is seen as being slightly more rational and sensitive than "teacher." Interestingly, although the social worker is seen as being sensitive, he is at the same time seen as being more remote than the teacher. 
TEACHING

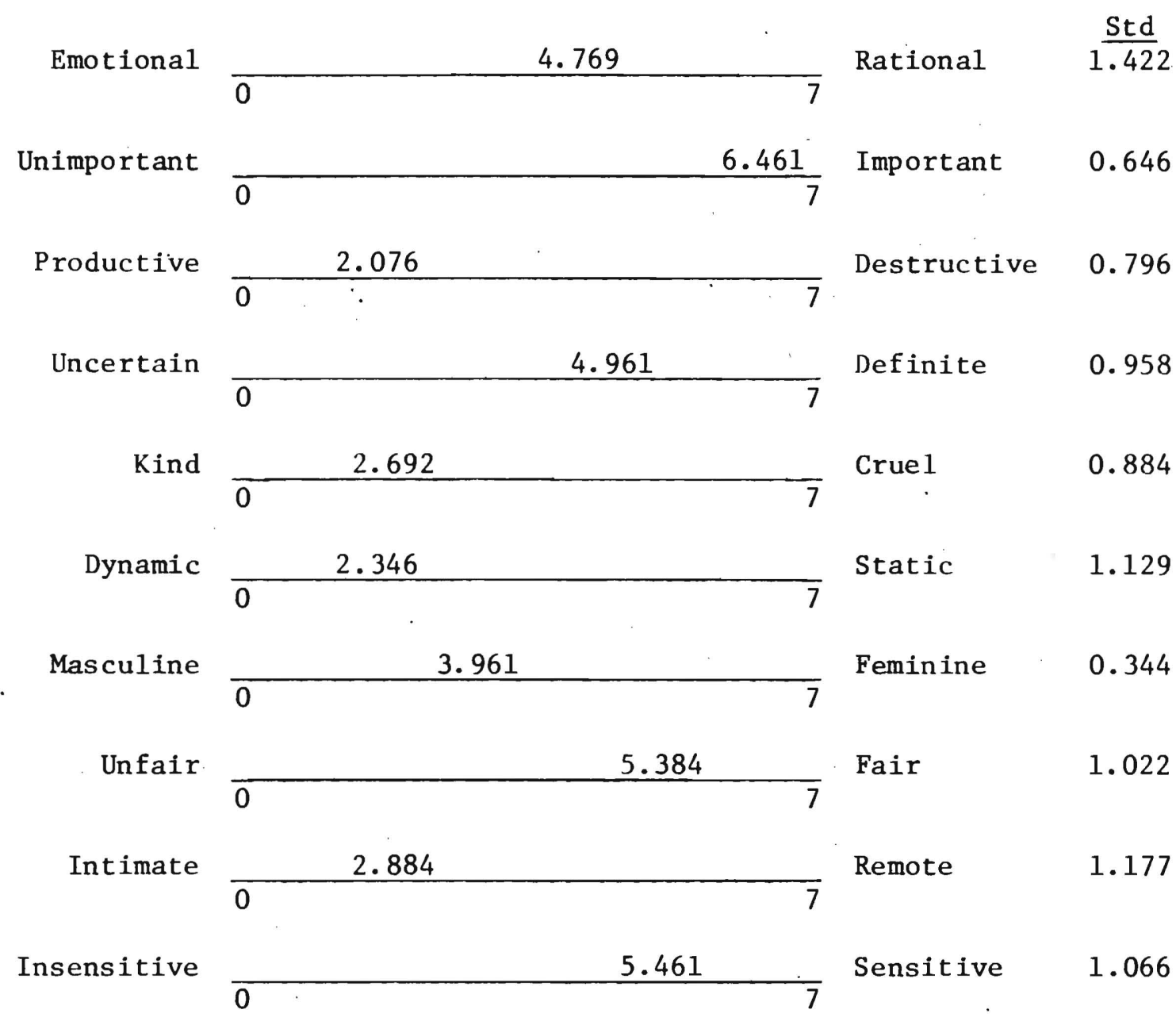

Teaching is viewed as an important function and there is significant agreement among the respondents as evidenced by the 0.646 standard deviation. Additionally, the concept is viewed as being productive, kind, dynamic, fair, intimate and sensitive. The indications are all towards the positive adjectives and the standard deviations indicate a collective agreement among the respondents. 
COUNSELING

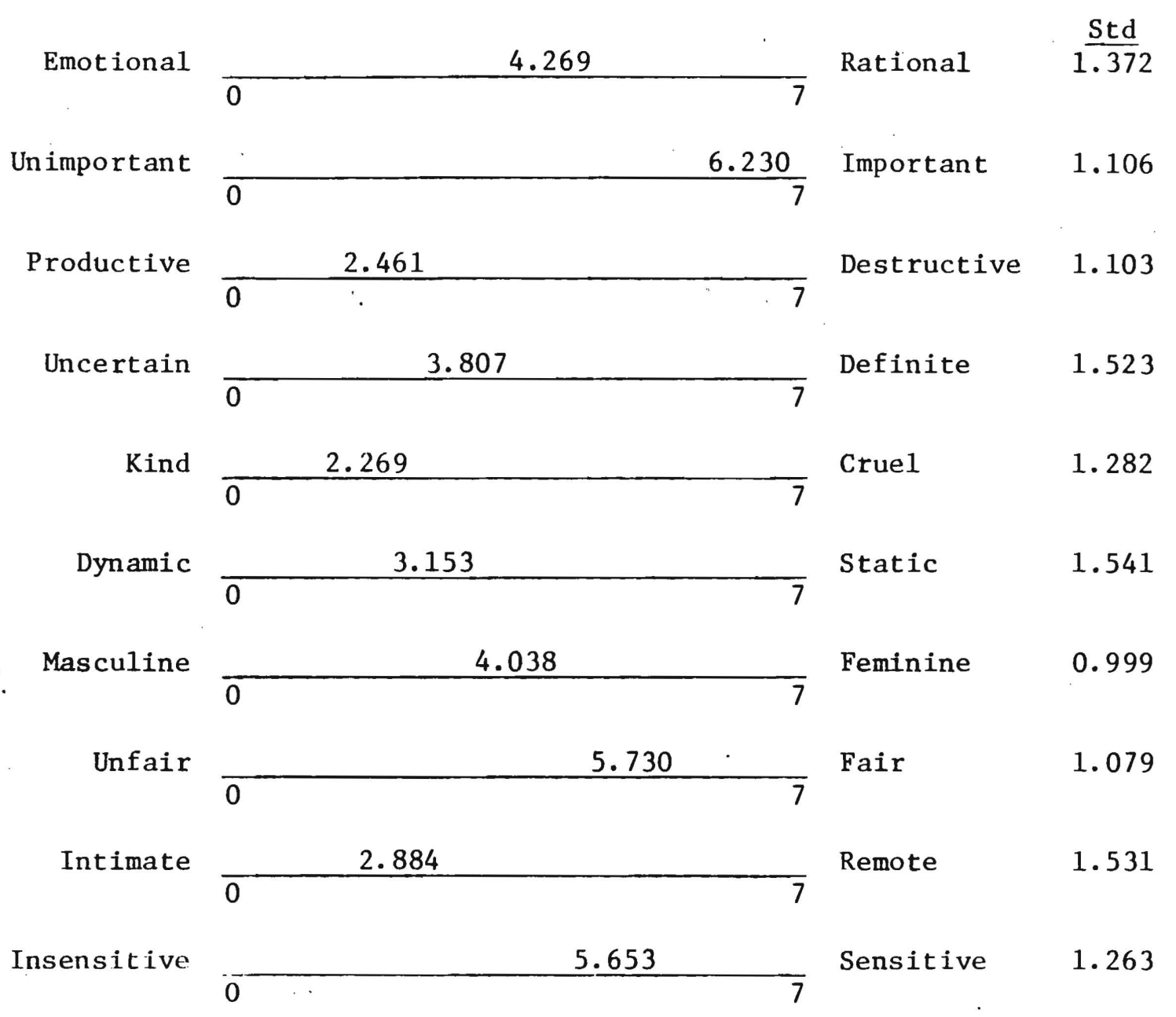

The concept "counseling" appears to produce a somewhat ambivalent response as evidenced by the more centralized mean scores. The uncertain-definite pairing produced a mean of 3.807 and the dynamic-static pairing produced a mean of 3.153. These responses would appear to indicate that teachers view counseling as a passive activity producing limited or suspected benefits. 
EDUCATIONAL COUNSELING

Emotiona1.

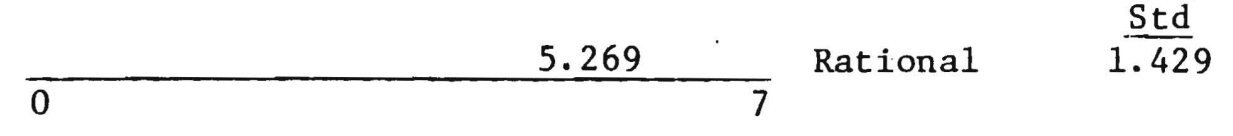

Unimportant

5.923

Important

Productive

$\frac{2.3}{0}$

Destructive $\quad 1.263$

Uncertain

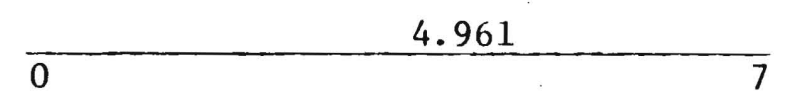

Definite

1.482

Kind

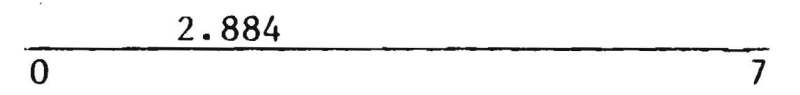

Crue 1

1.478

Dynamic

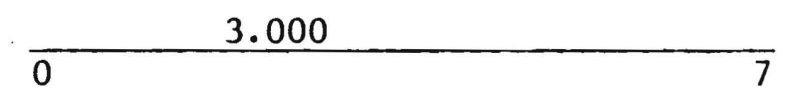

Static

1.264

Masculine

3.923

Feminine

0.483

Unfair

0

3.923

7

Fair

1.414

0

4.807

7

,

Intimate

3.346

Remote

1.695

Insensitive

5.269

Sensitive

1.662

Educational counseling is viewed as a rational, sensitive, and important function. Its productivity appears to be questioned and the dynamic-static pairing indicates an absence of forcefulness in pursuing this activity. In general, the responses indicate a "matter of factness" about the activity with strong feelings being noticeably absent. 


\section{CASEWORK}

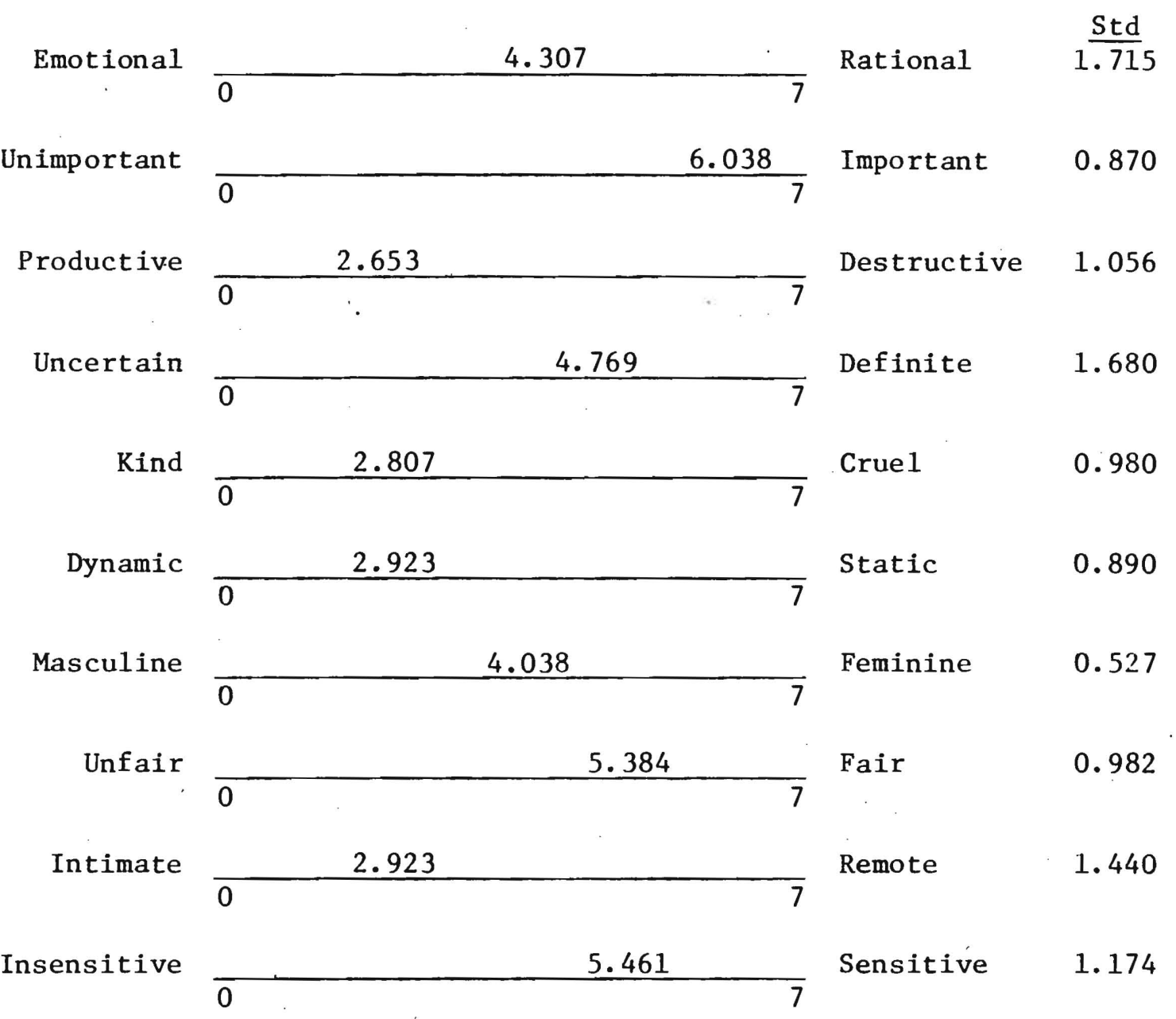

The concept "casework" produced data which indicates that teachers see this activity as being important, fair, and sensitive. However, the productivity, the dynamics, and the intimacy of the activity, while being viewed as positive, indicates skepticism from the respondents: 
$\underline{\text { FAMILY COUNSELING }}$

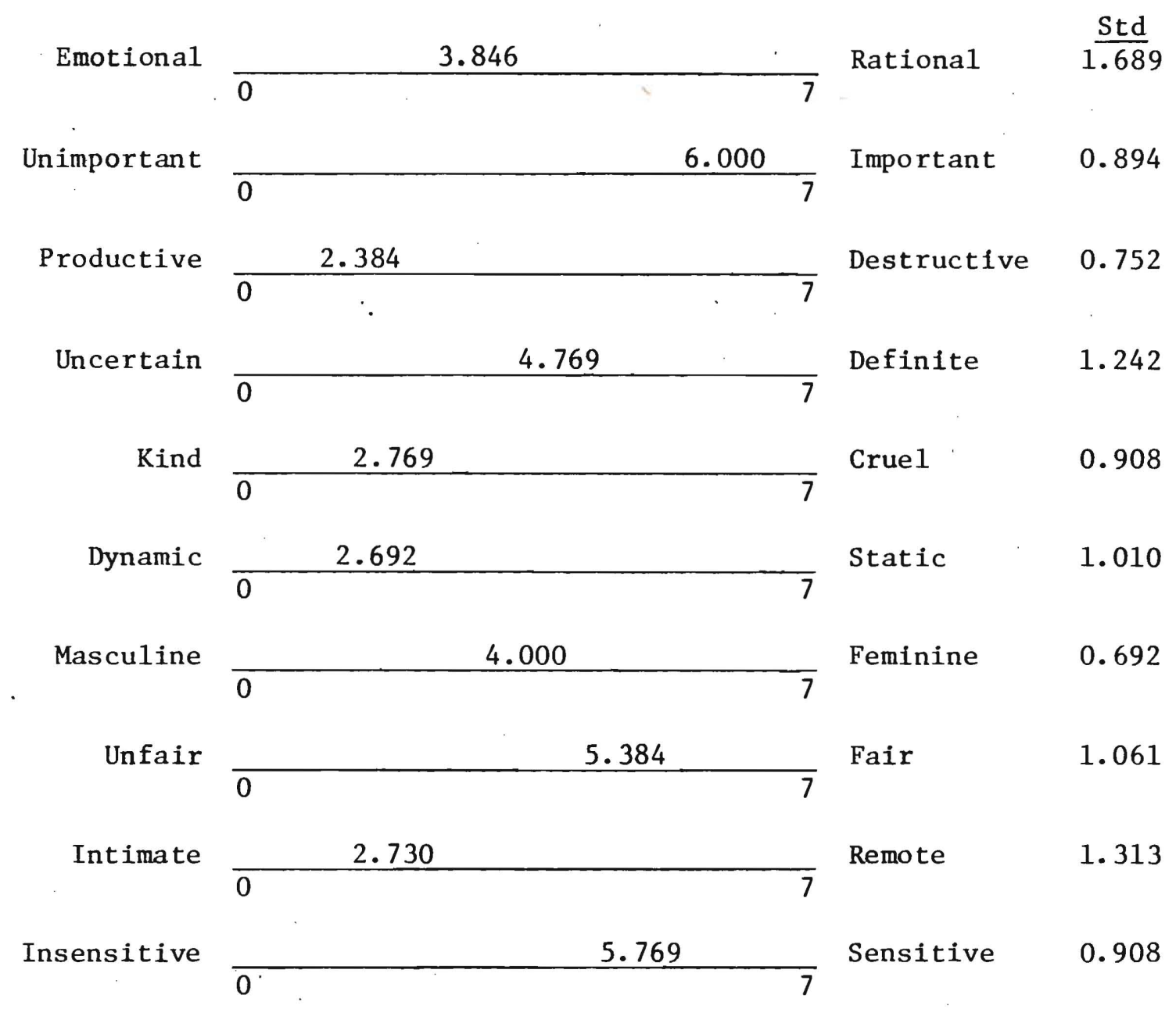

School social workers engaged in the task of family counseling are viewed by teachers as performing an important function that is basically fair and sensitive. However, they do not see it as being particularly rational, productive, kind, intimate, or dynamic. In essence there appears to be a committment to the concept as being important, but the usefulness of the activity is suspect. 
GROUP WORK

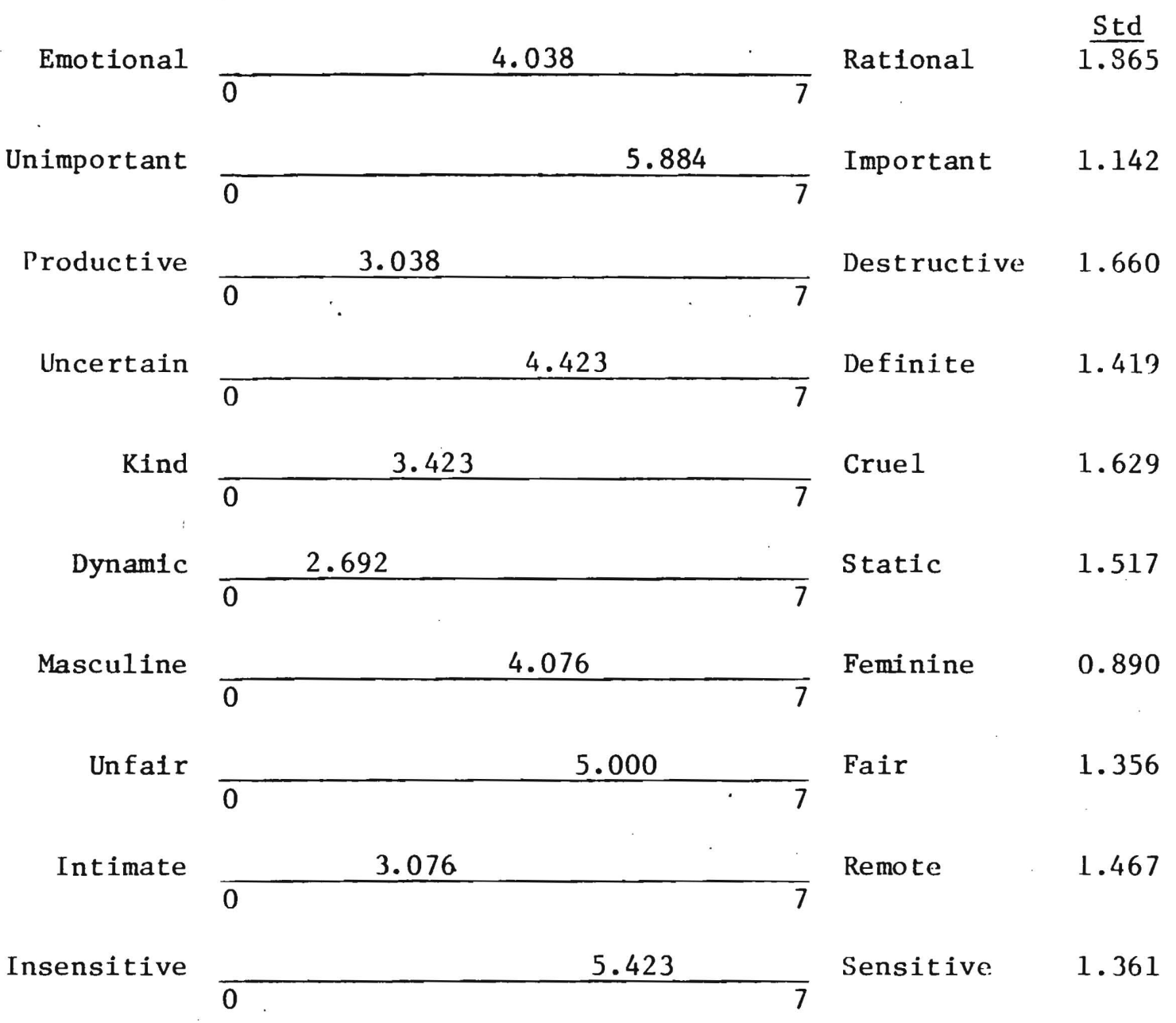

The concept "group work" produced data which indicates that as an activity of school social workers, it ranks lower than either casework or family counseling. This may represent the respondents' increased exposure to the other concepts as they are practiced more frequently by school social workers. 
CONSULTING

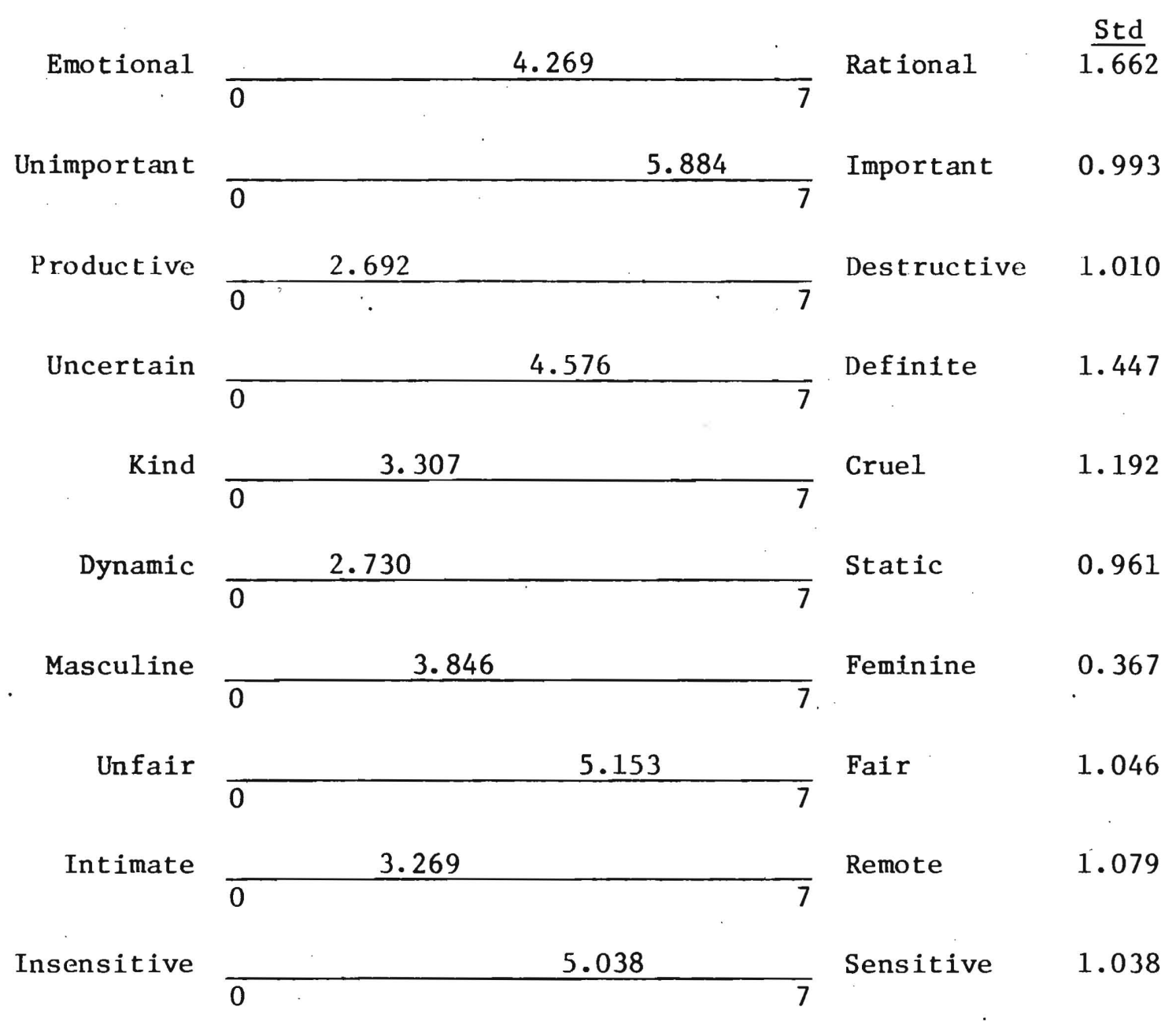

Consulting produced data which indicates that school social workers in this capacity are viewed in a more impersonal light. The activity is viewed as neutral on the kind-cruel pairing as well as on the intimate-remote pairing. These responses appear to indicate that their experiences have been positive although productivity is again questioned. 
EMPLOYMENT COUNSELING

Emotiona1 $5.346 \quad \frac{\text { Std }}{1.383}$

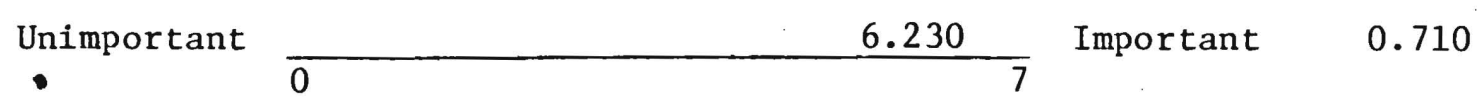

Productive $\frac{2.500}{0} \quad$ Destructive 1.140

$\begin{array}{llll}\text { Uncertain } & 4.923 & \text { Definite } & 1.440\end{array}$

$\begin{array}{llll}\text { Kind } & 3.076 & \text { Crue } 1 & 1.128\end{array}$

$\begin{array}{lrrr}\text { Dynamic } & 3.384 & \text { Static } & 1.267\end{array}$

$\begin{array}{llll}\text { Masculine } & 3.692 & \text { Feminine } & 0.549\end{array}$

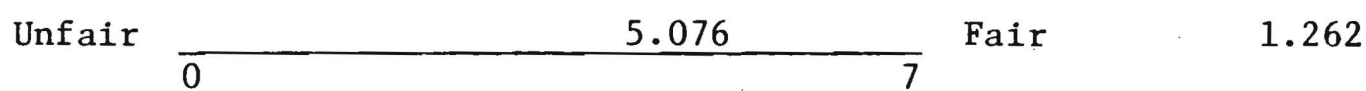

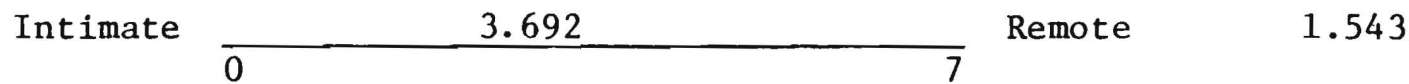

Insensitive $\begin{array}{lll}4.692 & \text { Sensitive } & 1.349\end{array}$

The school social worker providing employment counseling is seen as performing an important, fair, and basically rational service. Again the productivity and the forcefulness of the activity appear to be questioned by the respondents. However, this may represent the attitude that this is basically an information giving function and attributes of sensitivity, kindness, and intimacy are not required. 
MINORITY STUDENTS

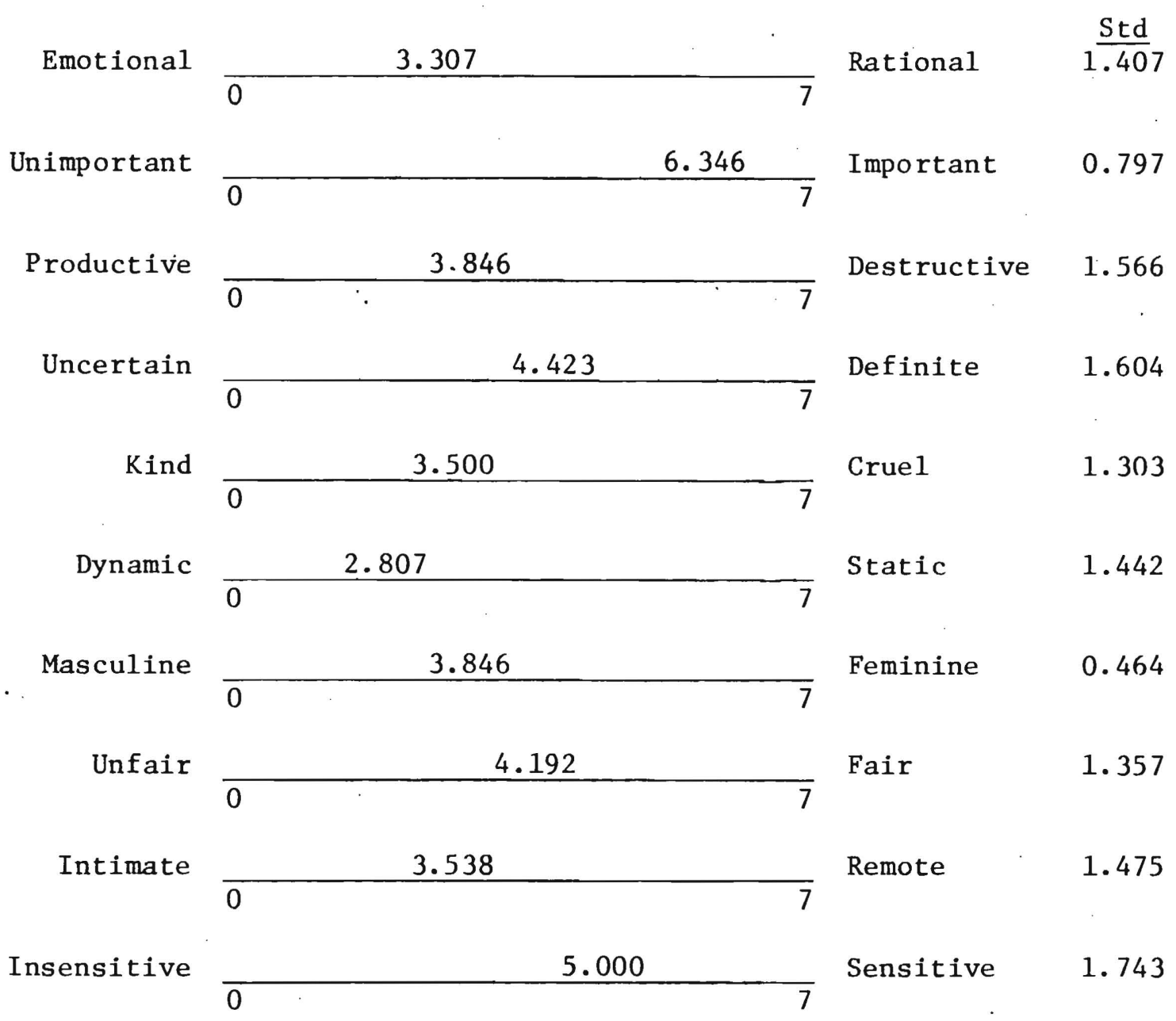

The concept of "minority students" produced data which indicates that this is an important area for school social workers to address themselves and that it requires a significant amount of sensitivily. Interestingly, they do not see this as being a rational activity nor one that requires significant amounts of kindness or intimacy. 
WELFARE FAMILIES

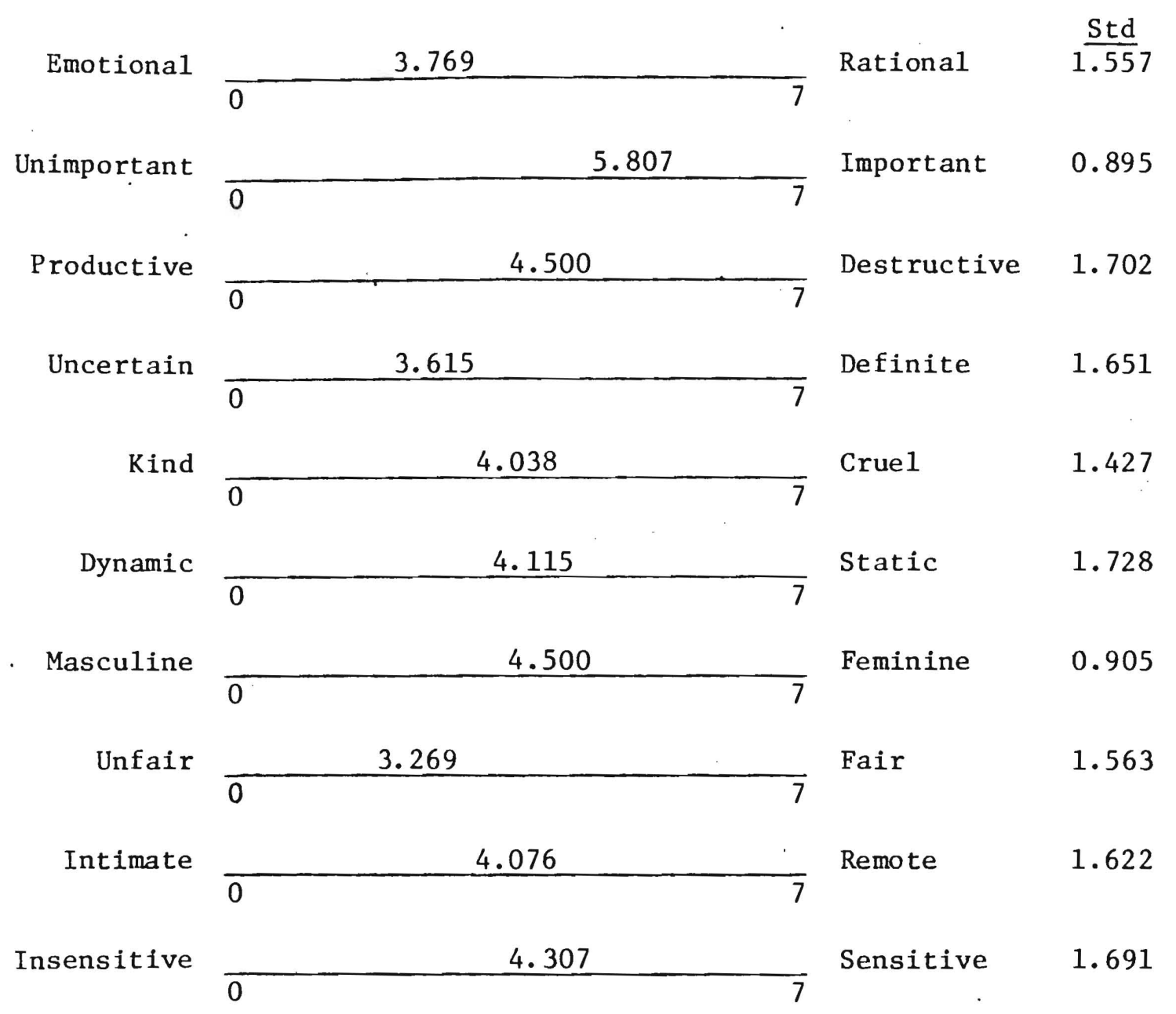

The concept "welfare families" produced data which suggests that its priority ranks below minority students and truancy as concerns for school social workers. The central positioning of the mean scores suggests that the often heard identification of social workers with welfare families does not exist. 
TRUANCY

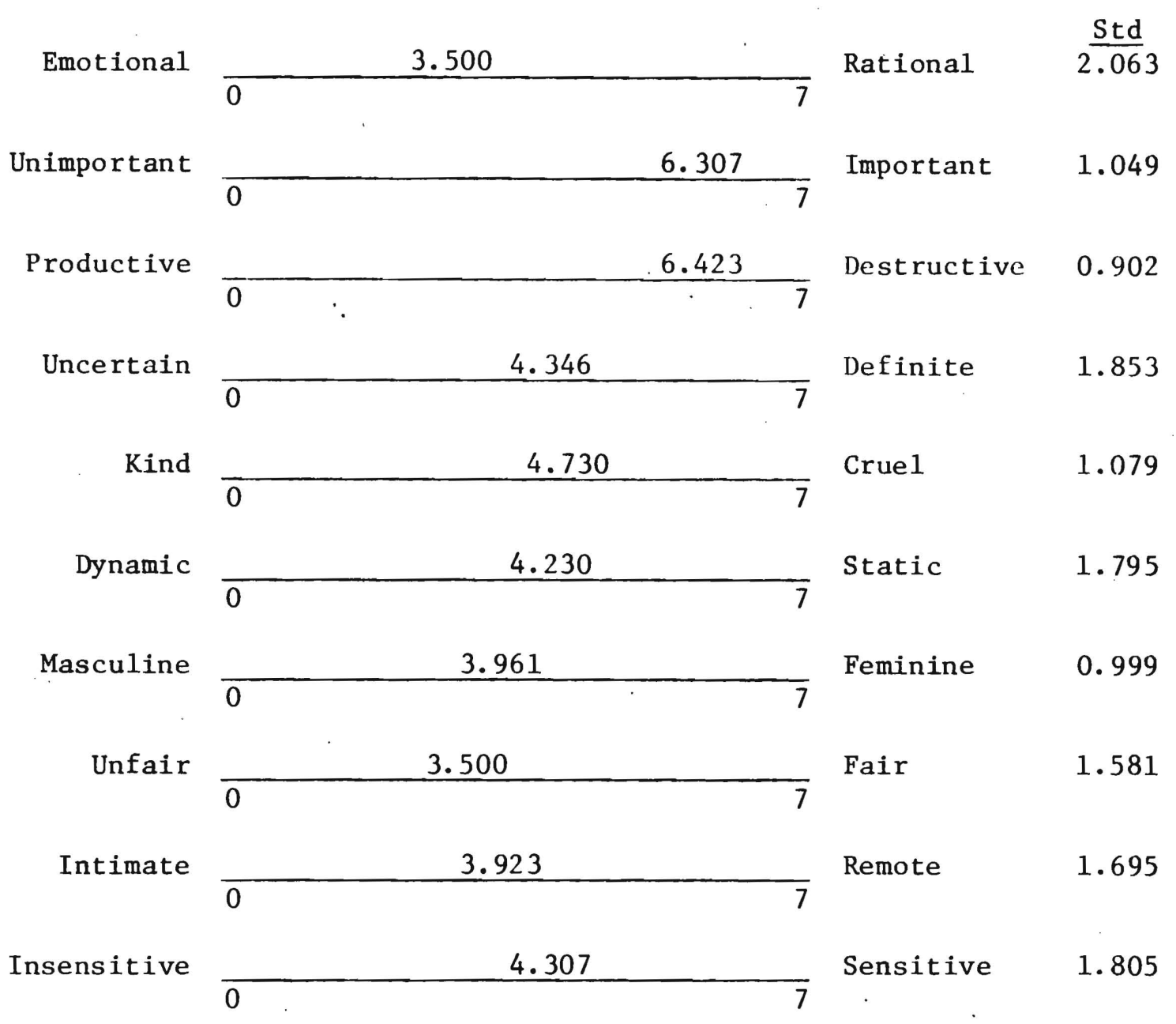

The responses to "truancy" suggest that teachers see this concept as an important area of concern for school social workers. The mean on the productive-destructive scale reflects a concerned attitude for students experiencing this problem. The remainder of the scales suggests that an attitude of hopelessness prevails in regards to assisting students with this difficulty. 
COMMUNITY ORGANIZATION

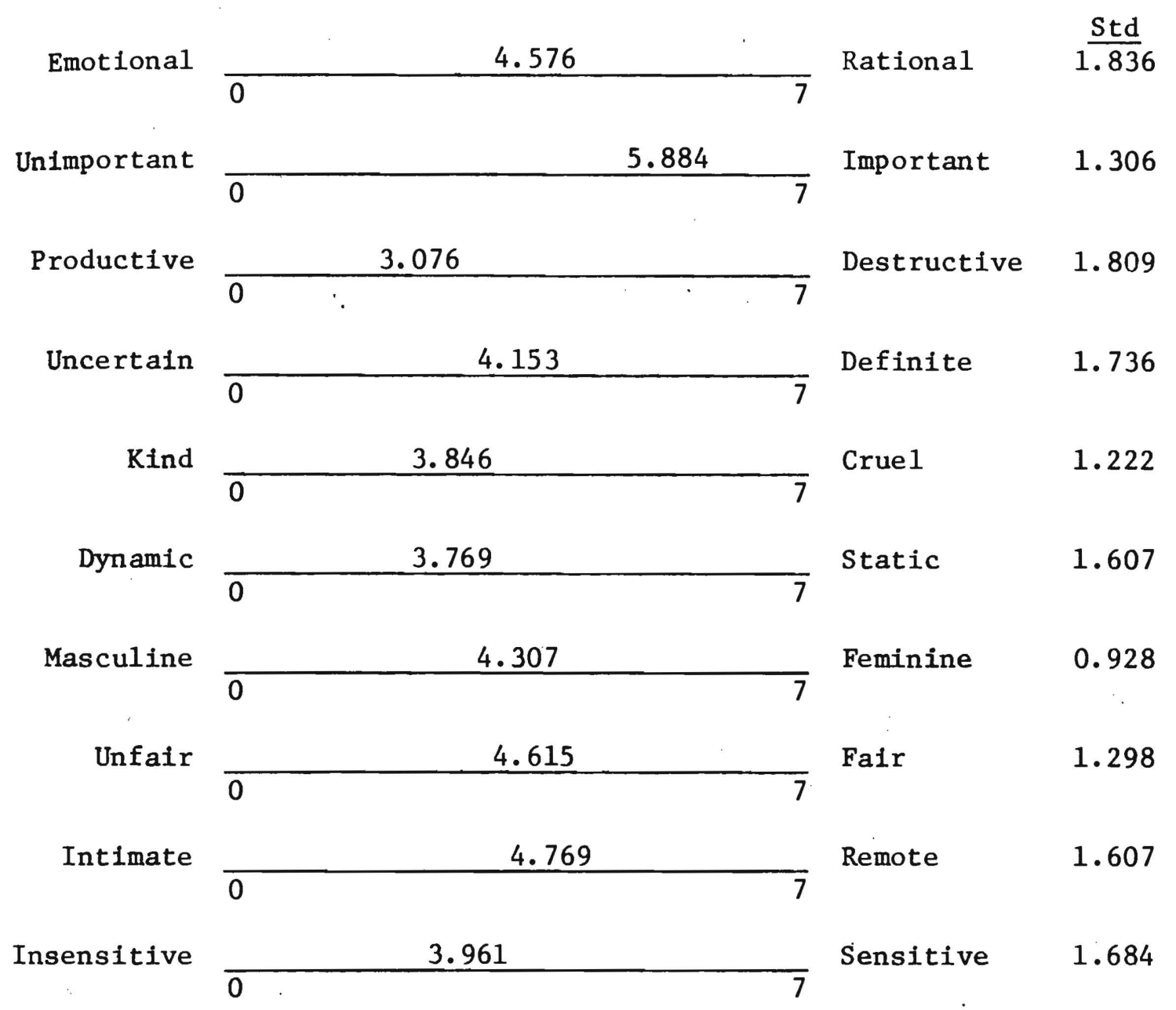

School social workers engaged in community organization projects fail to achieve a significant level of support from the respondents. As an activity it ranks well below casework, family counseling, and educational counseling. However, this may again reflect the teacher's experiences with school social workers and seeing them operate within a casework framework in most situations. 
REFERRING

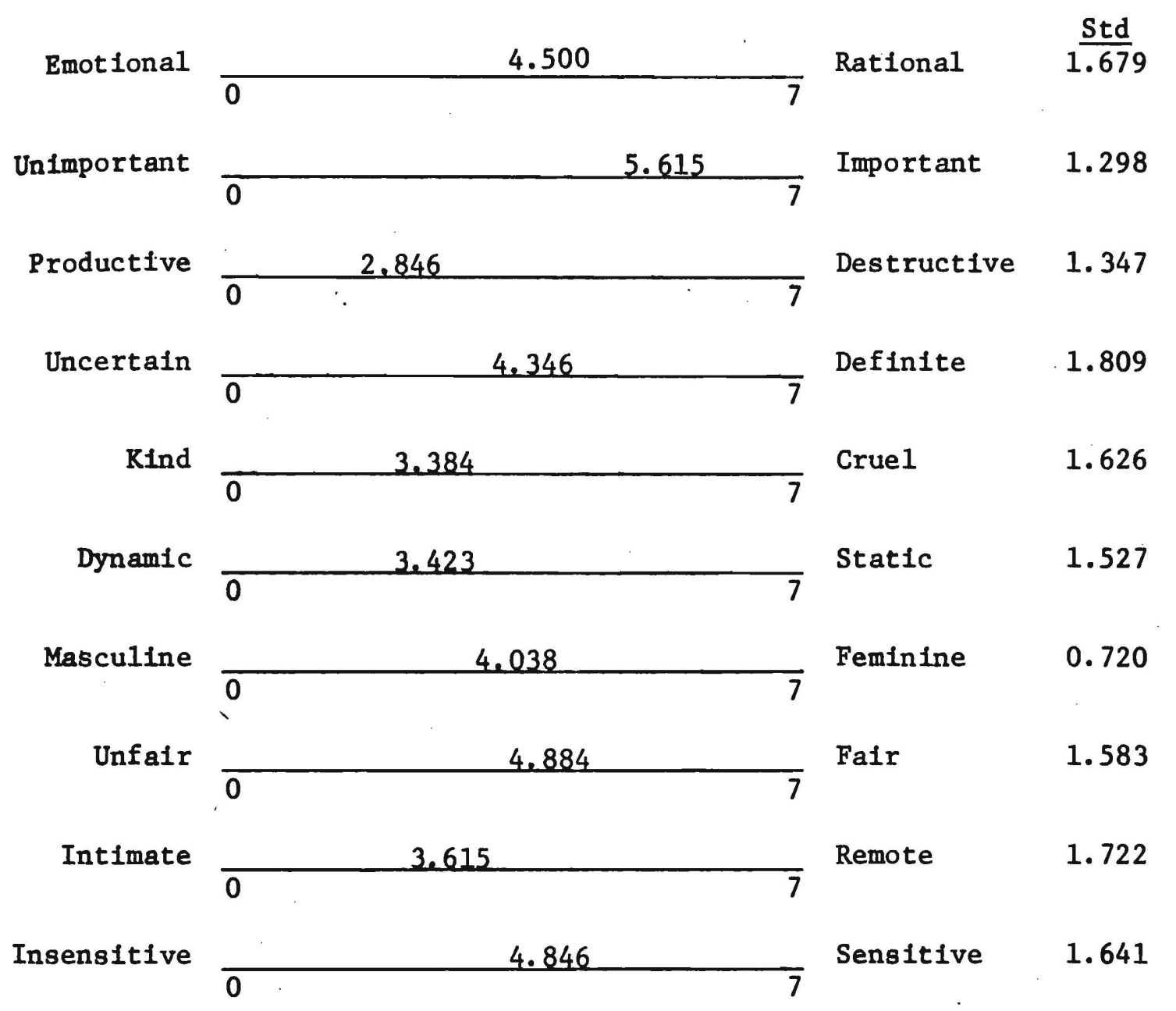

As an activity, referring produced data showing limited support from the teachers. It achieved a mean score on the important scale of only 5.615 in comparison to the other concepts which demonstrate higher results. The remaining responses indicate that the process is viewed as being a matter of fact operation. 
RESEARCH

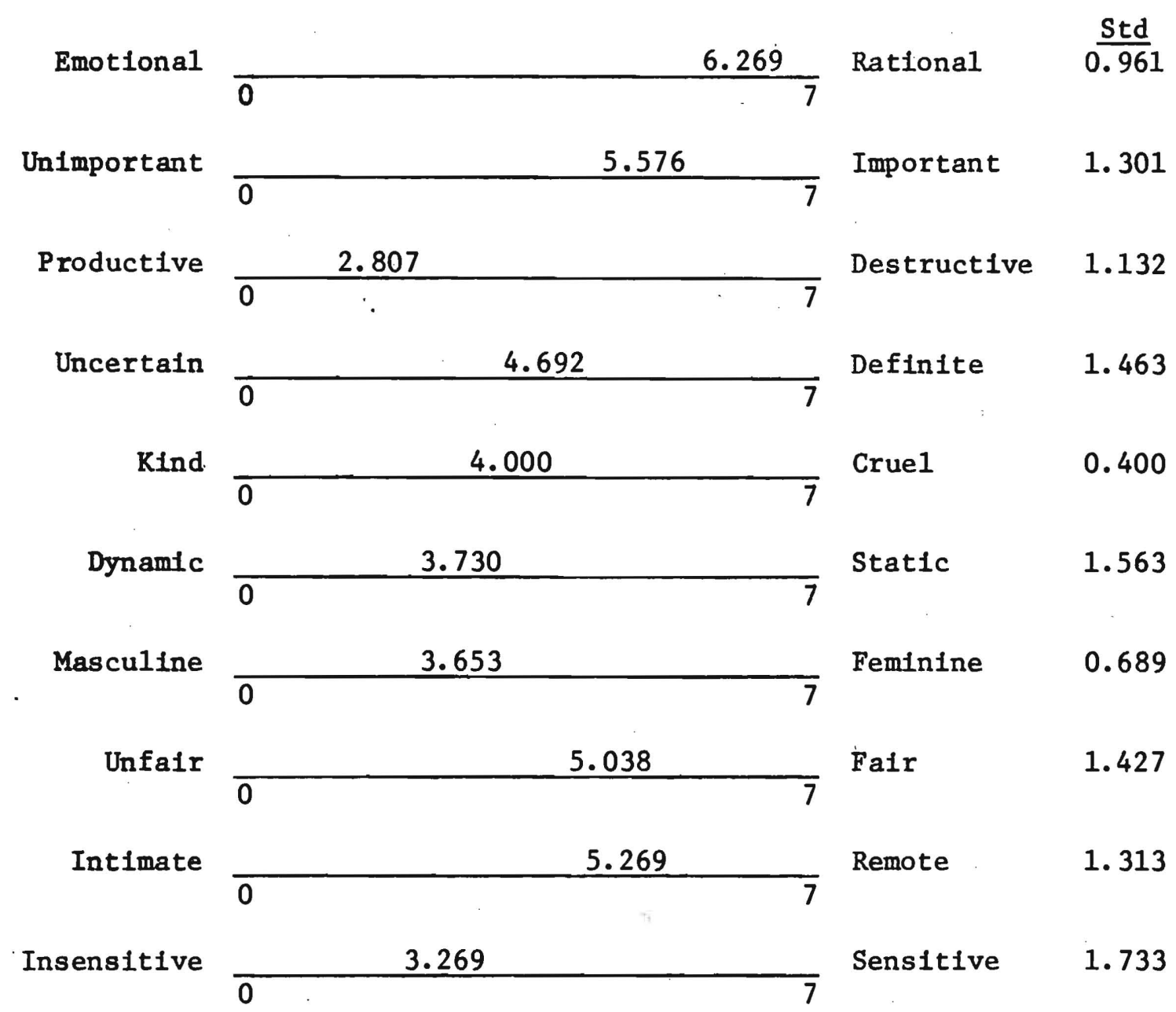

The concept "research" as an activity for school social workers produced surprising results. The respondents view this as an extremely important activity. Further, this activity is viewed as highly rational, fair, but somewhat remote. The remaining scores suggest that the activity is seen as one not requiring significant amounts of interpersonal skills. 
CHAPTER IV

CONCLUSIONS

This study has been concerned with the attitudes of teachers towards school social workers and their roles at John Adams High School. Our goal was to obtain reliable data to see if there was a significant difference in teachers' attitudes versus school social workers' assumptions. These assumptions were developed into two null hypotheses, but the large amount of data and the shortness of time prevented us from analyzing all the data as well as proving or disproving the two null hypotheses. All statistical information was gathered and analyzed by standard deviation and mean. From the information it would appear to indicate:

1. That teachers at John Adams do not see school social workers as effective in a school setting.

2. That teachers at John Adams are aware of the functions of a school social worker in a public school setting.

Because of the limited amount of data analyzed, further statistical analysis must be done to prove or disprove the two null hypotheses.

The analysis of the concepts found that three were more important than the rest of the concepts. The three being the concepts of "self," "teacher," and "teaching," where the mean was greater on these particular concepts. 
Every concept was seen as important by the respondents. But when it came down to the productiveness, the dynamics and the intimacy, the respondents began to question the social work profession. They questioned the area of practice in school social work and had ambivalent feelings to whether school social workers are productive or useful. Conclusions drawn from the data would indicate:

1. That the respondents' experience with school social workers has not been helpful, but a further research to determine why teachers are responding in this fashion is needed.

2. The respondents saw that education is the primary function In a school setting and school social workers are a secondary service. This low priority was reflected in a higher mean score and a lower standard deviation. The concepts analyzed were "self," "teacher," and "teaching," compared to the remaining concepts.

3. School social work is not seen as either a masculine or feminine function.

4. Of the normal modes of operation by school social workers, which include casework, group work, family counseling, community organization and consulting, casework is seen in the most positive 1ight. Interestingly, the greatest ambivalence Is shown towards the concept of "consulting."

5. Often, the expressed or held opinion is that social workers are identified as working with welfare families or the racial minorities, which is not implied by the data. This Is reflected in the response of the concepts "welfare families" and "minority students." 
SUMMARY

It would seem appropriate to implement further research in a . follow-up study. This recommendation is a result of the extensive amount of statistical data and measurements that were not utilized. But for our particular purpose, we only used the mean and the standard deviation of all the concepts. In addition, the researchers would recommend that school soclal workers at John Adams become consistent In follow-up contacts with teachers in regards to a student referral. This lack of follow-up has hindered positive consultation between teachers and school soclal workers. This would tend to work in a perpetual cycle of questioning whether school soctal workers can perform functions well or whether what they do is productive. 
Alderson, John J. (ed.). Social Work in Schools: Patterns and Perspectives. Illinois, Whitehall Co., 1969.

Costin, Lela B. A Historical Review of School Social Work. Social Casework, October 1969.

Johnson, Arlien. School Soctal Work: Its Contribution to Professional Education. New York, National Association of Social Workers, 1962.

Osgood, Charles E., Suci, George J. and Tannerbaum, Percy H. The Measurement of Meaning. Illinois, University of Illinois, 1957.

Rapaport, Lydia. Consultation in Social Work Practice. New York, National Association of Social Workers, 1963.

Sarr1, Rosemary C. and Maple, Frank F. (eds.). The School in the Community. Washington, D.C., National Association of Social Workers, Inc., 1972.

Silberman, Charles E. Crisis in the Classroom. New York, Random House, 1970. 
APPENDIX

TEACHER ATTITUDINAL STUDY: QUESTIONNAIRE 
TEACHRR AIIITUDINAI STUDY: QUESTIONNAIRE

You have been selecred from a sample of John Adams faculty to particlpate in an evaluation of teachers' attitudes regarding school social workers. Tour participation in thls study will provide information that will be helpful in Impriving the fumction of soclal workers who work in educational settings.

The questionnalre consists of a number of concepts to which you are asked to Indicate your responses. Please give all items your careful consideration. Your responses will be very Important because you w11 in effect be representing the views of your fellow teachers who were not selected. All Individual responses will be treated confidential1y.

Your cooperation is sincerely appreciated.

Thenk you.

Ray Merritt \& Drayne Mcliamnay Social Work Graduate Students Portland State University 


\section{DEMOGRAPHICAI INPORMATION}

8EX:

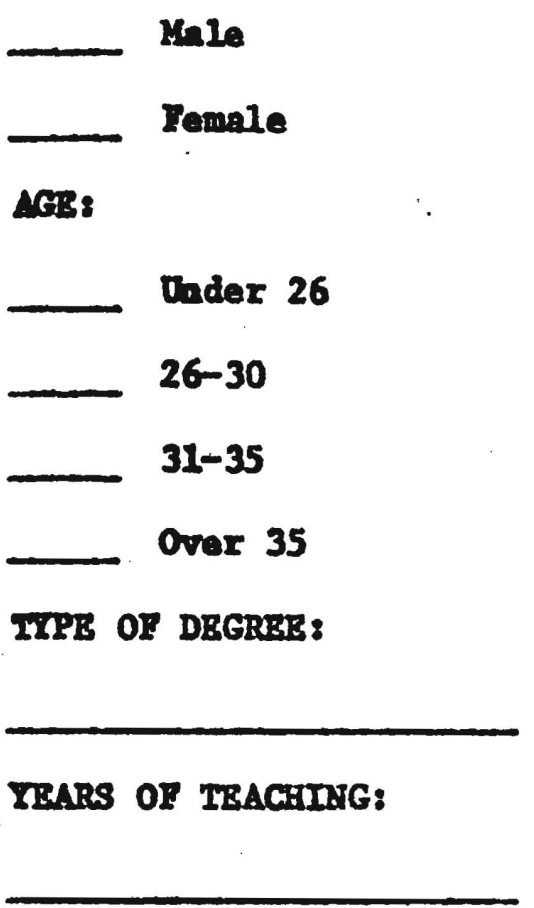

BTHAIC BACKGROUND:

Bon-Minority

Black

Chlceno

Aalan

Native American

Other

DBPARTIMANT AT JOEN ADAMS:

In capacity of teacher, have you utllized the service of a social worker? YES No

Yrars AT JOHN aDAMS hIGH SchOOL:

MARITAL STATUS:

single

Marriad

D1voreed

Separated

W1dowed 


\section{INSTRUCTIONS}

The purpose of this study is to measure the meanings of certain things to various people by having them judge them against a serles of descriptive scales. In taking this test, please make your Judgments on the basis of what these things mean to you. On the following pages you will find different concepts to be Judged and beneath each a set of scales. You are to rate the concept on each of these scales In order.

Here Is how you are to use these scales:

If you feel that the concept at the top of the page 18 vexy closely related to one end of the scale, you should place your check-mark as follows:

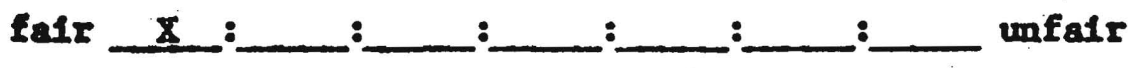

OR

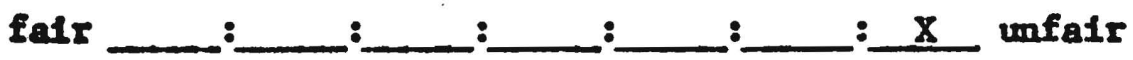

If you feel that the concept is gufte closely related to one or the other end of the scale (but not extremely), you should place your check-mark as follows:

etroag $\mathbf{x}$ : : : : weak

OR

$0 t 50038$ $-$ weak

If the concept seems only allghtlp related to one side as opposed to the other side (but is not really neutral), then you should check as Lollows:

active

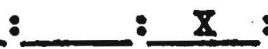
: $-$ : passive

OR

active : : -

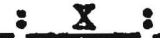
: passive

The direction toward which you check, of course, depends upon which of the two ends of the scale seem most charecterlstic of the thing you' Ie Judging. 
If you consider the concept to be neutral on the scale, both sides of the scale equally assoclated with the concept, or if the scale is completely 1rrelevant, unrelated to the concept, then you should place your check-mark in the middle space:

safe $-$ : :: dangerous

IIPORTANT: (1) Place your check-marks in the middle of spaces, not on the boundaries:

[

(2) Be sure you check every scale for every concept do not omit any.

(3) Never put more than one check-mark on a single scale.

Sometimes you may feel as though you've had the same item before on the test. This will not be the case, 80 do not look back and forth through the 1tems. Do not try to remenber how you checked simflar Items earlier in the test. Make each Item a separate and Independent fudgmant. Work at falrly high speed through this test. Do tot worry or pueale over Individual 1tems. It is pour first Impressions, the 1mmediate "feelings" about the 1tems, that we want. On the other hand, please do not be carelass, becsuse we want your true 1 mpressions. 
Buotional

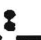
: : : : $-$ Rational

Ontmportant : : : : : Inportant

Productive

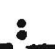
: : : Destructive

Dncertaln : : : : Definfte rind : : : : _ Cruel

Dynamic : : :

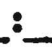
Stat1c Masculene 2 :$\therefore$ : $\therefore$ Femintne Dnfalr : : : : : : Ralr

Intimate : : : $\therefore$ : Remote

Insensit1ve : : $-$ $-$ : :Sensit1ve 
Botional : 8 $-$ 2 8 : Rational

Untportant $-$ : : 8 Inpoctent

Exaductive :

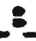
: : Destmetive

Decextaln ' $-$ 8 : : Defintte rind ${ }^{3}$ :: Cruel Dynamie $-$ : $-2$ :

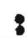
static

Mascullne

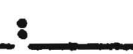
: $:$ : : Feminine

Dnfalx : : : : Bair

Intimate : : 8 : Ramote

Insensitive 8 : $-$ : 8 $-$ Sensitive 


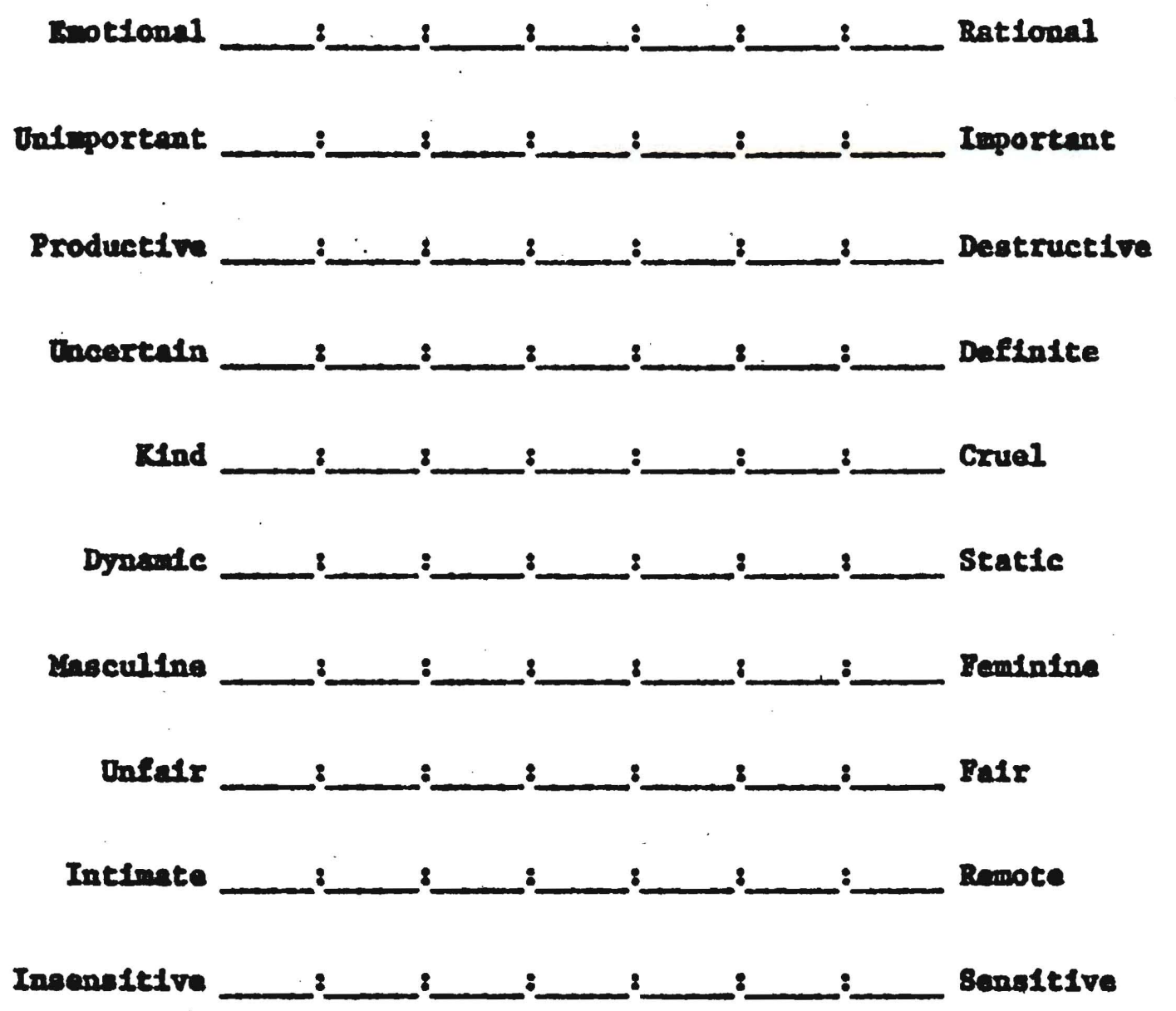


Bmotlonal : :

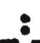
$-$ 8 Rational

Unfmportant : 3 $-$

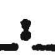
Irportent

Productive 18 28 8 Destruetive

Uncerteain 8

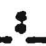
8 8 $-$

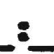
Definte Kend $-$ $-$ Crue1.

Dyante : $-$ : $2^{8}$ static

Mecutine

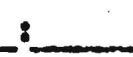
8 : : $-$ : Beminine

Unfalr $-$ : $-$ 8 : Patr

Incimace : $-$

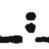
$-$ 2 2 Remote

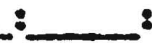
: :

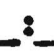
2 Bensltive 
Bmotional : $-$ : : 8 Rational

Untrportant $-$ : Important

Productive $-$ : :

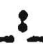
Destruct Ive

Uncertain : :8 : Definite Rind : : $-$

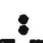
Cruel

Dynamic : : :

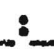
: Static

Mascullne : $: 8$ 2 $+$ $-$ Fenisine Onfatx : $-$

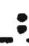
Paix Intimste : : : Remote : $\therefore$ : Sensitive 
Brotional : :

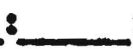
$+$ $-$ Rational

Unixportant : 2 $-$ Inportent

Productive $\therefore$ $-$ $-1$ Destructive

Uncertaln $-$ 8 8

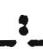
: Defintea

$$
\text { Kind }
$$
$\sim$

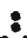
. : 8 $-$ Cruel

Dymanic $-$ : : : Statie Masculine

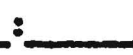

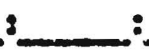
: $-$ $-$ Penintne Unfalr : :

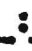
: Talx

Intimate : : : 3 Remote : : : : $-$ Sensitive 


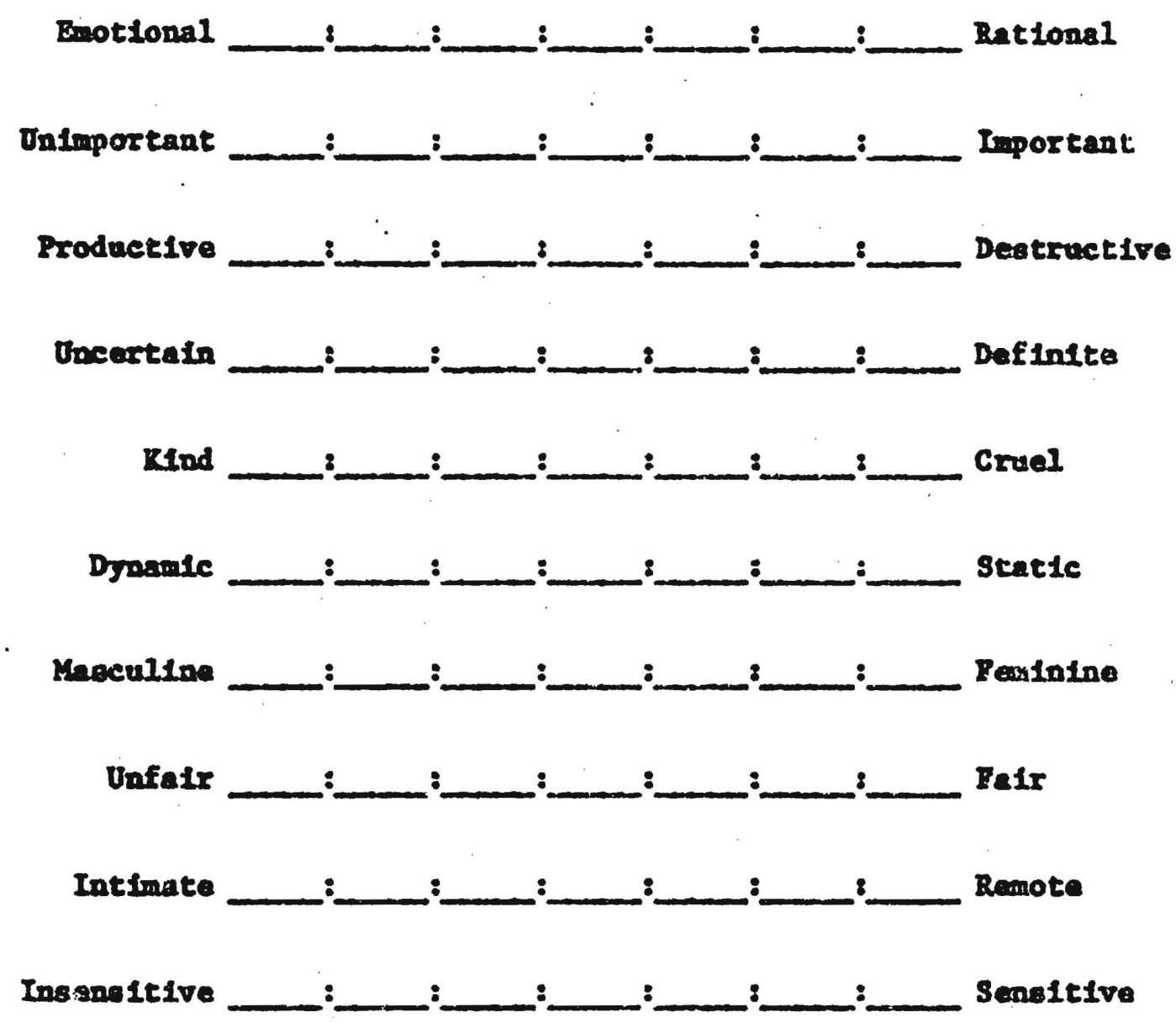


RETSERRING

Butlonal : :

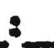
:: $-$ Rational

Unsmportant : : $-$ $-$ : Iriporent

Productive $-$ : : :2 Destructive Urcertain $-$ $-$

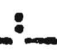
: Definte

Red : $:$ : Crual

Dyonare : :

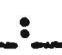
2 : Static

Meculine : : : $-2$ : Peninine

Onfalr : : 2 : Fais Intinete

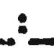
: : : Remote

Insensitive : :

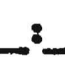
: 8 Sensitive 
Eotlone1 2 $-8$ 2 8 8 Rnetoonl

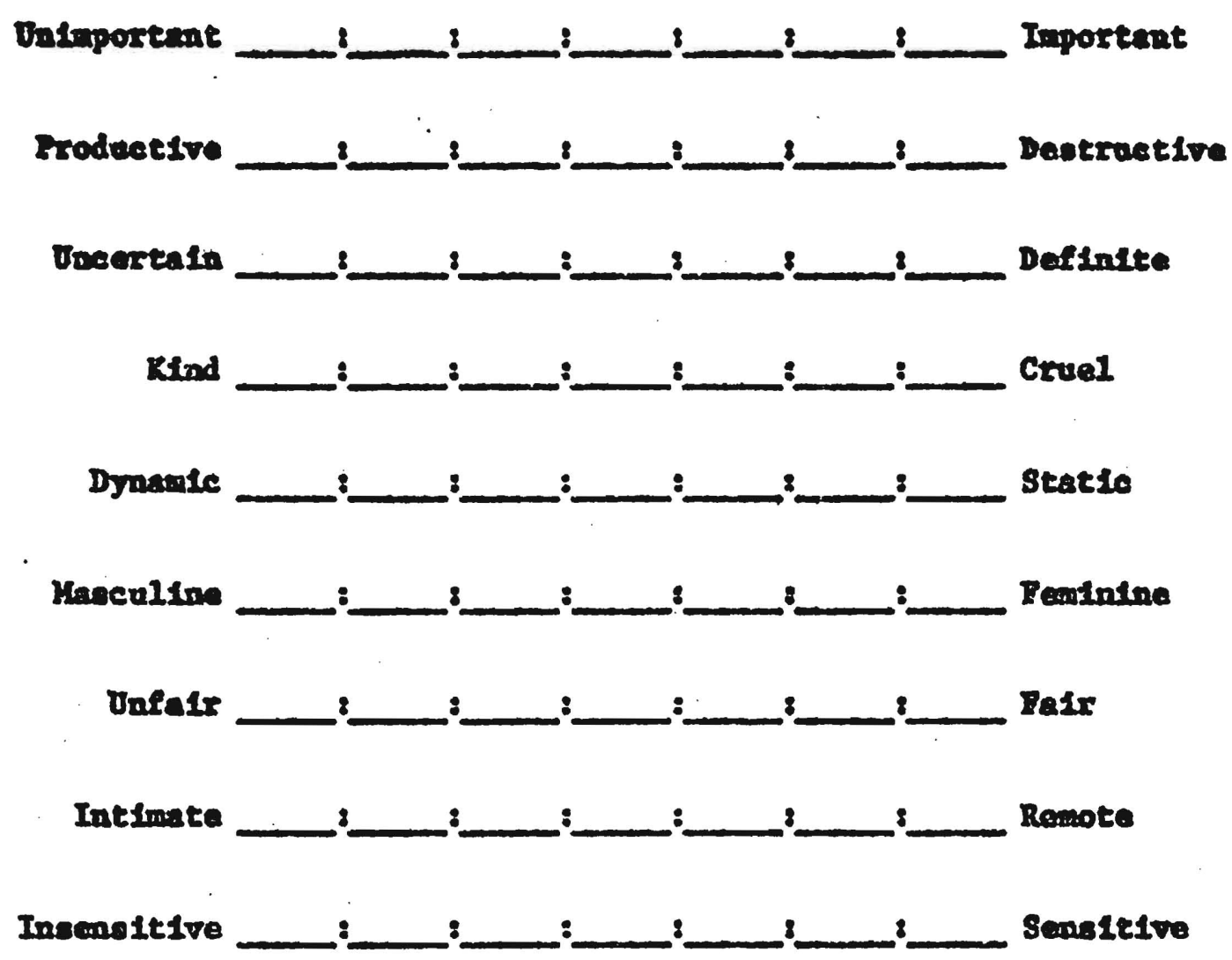


SCBOCL SOCIAI WORCA

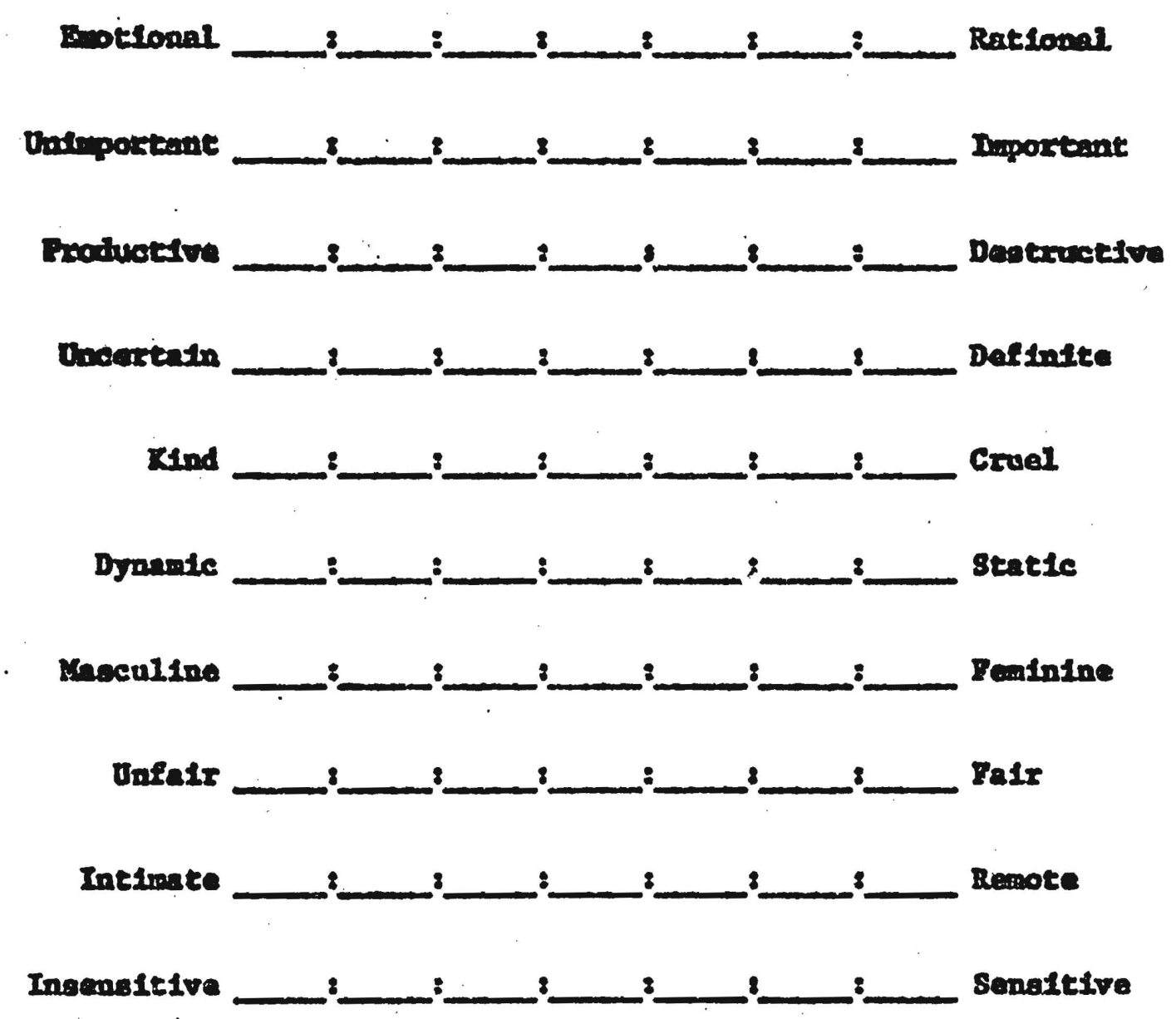




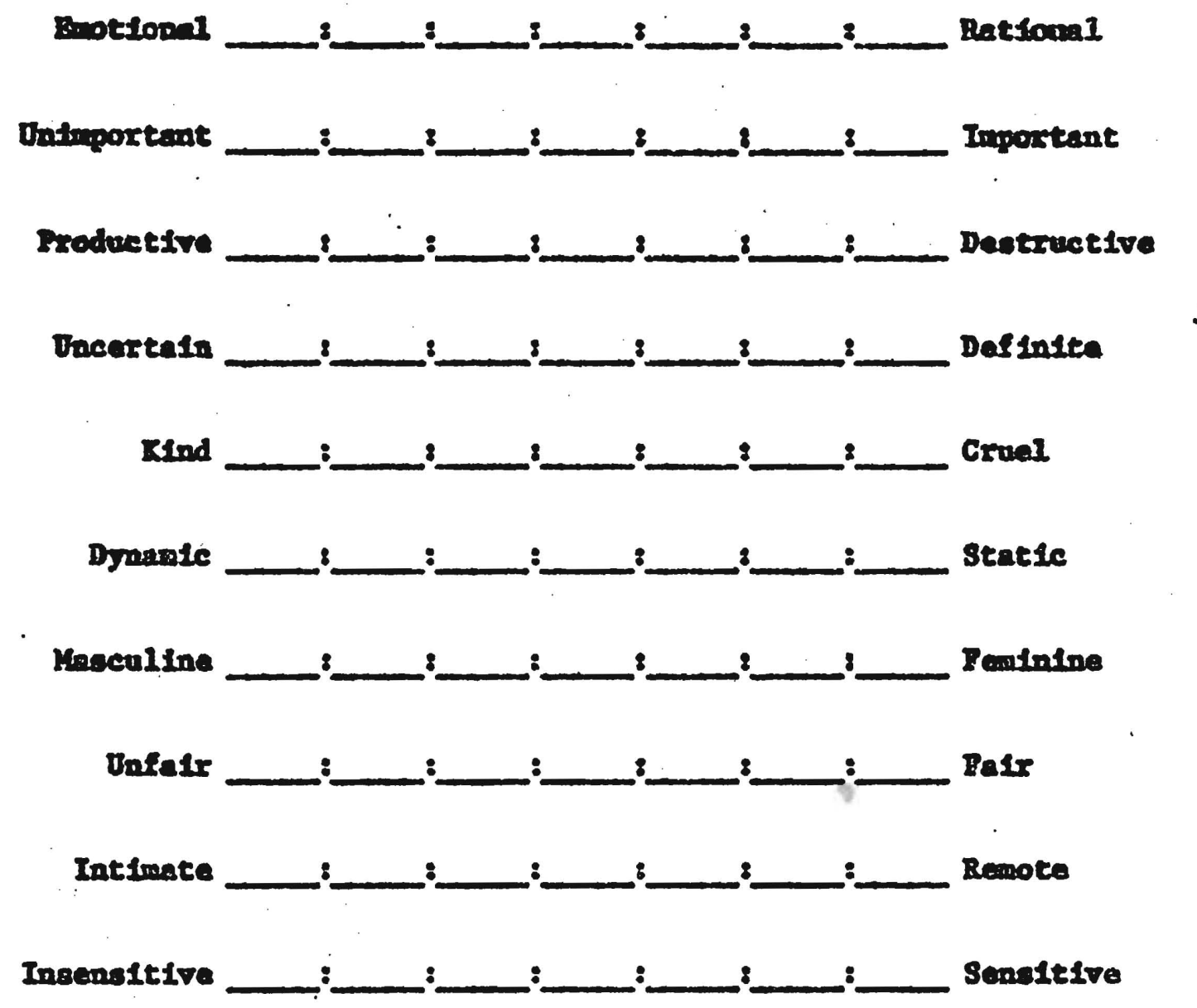




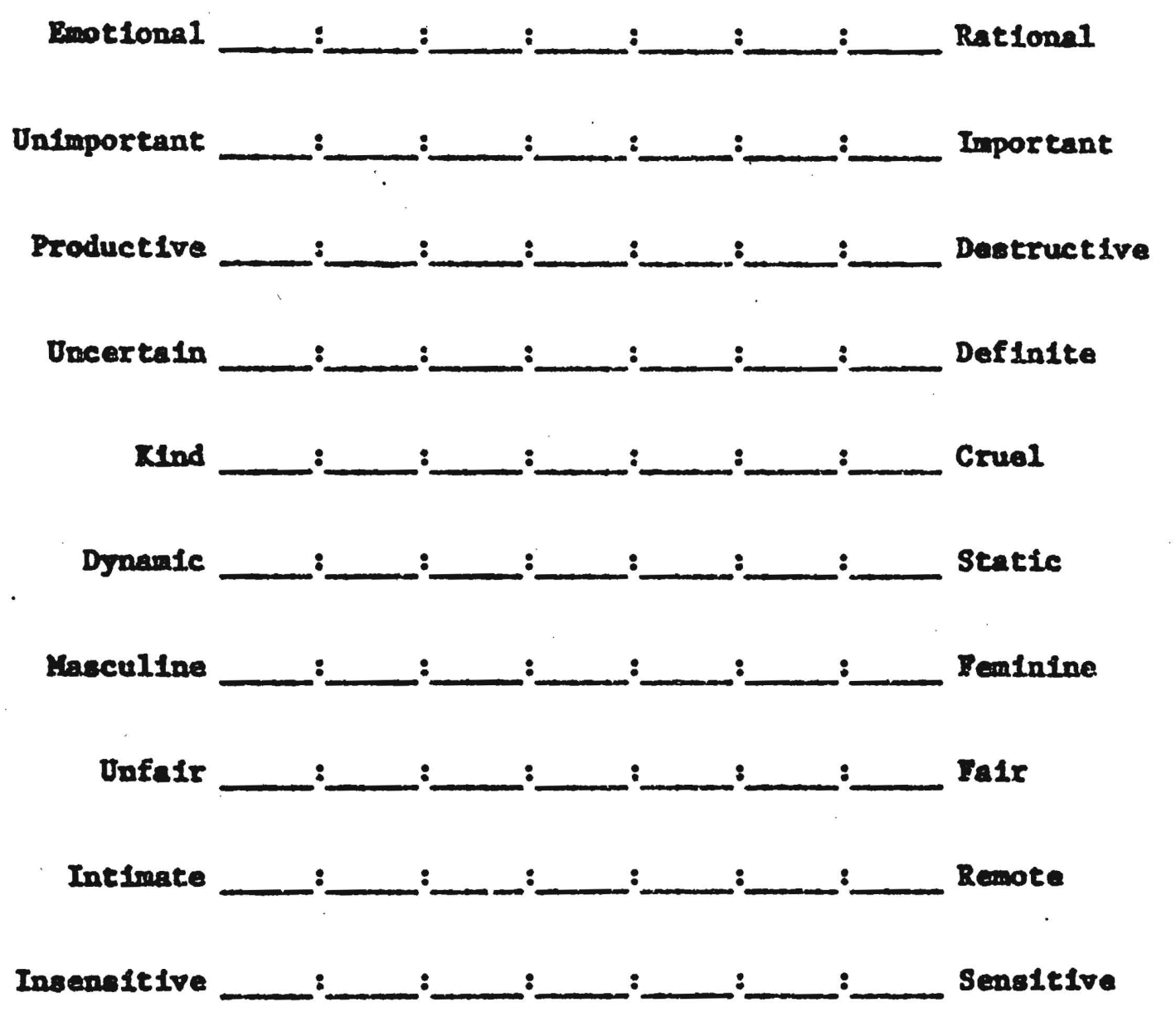


coisurytin

Dotsonal : 8

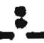
2 8 Ratsonal

Dratuporenne 2 8 Inpestint

reductere 8 :3 2 Deoturustive

Desexten

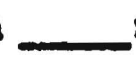
8 8 :

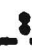
Dafinste reind 2<smiles>C1CCCCC1</smiles>
8 $-2$ ${ }^{8}$ Grual

byonete : $-$ $-$ 8 2 8 Stente

Mnewitn 8 $-$ 8 indine Onfals $-$ $-2$ 8 8 Past

Intinnte

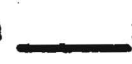
8 $-3$ 8 8 3 Renote

Insensteive

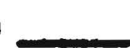
8 $:$ ${ }^{3}{ }_{-}^{2}{ }_{-}^{2}$ 8encitive 


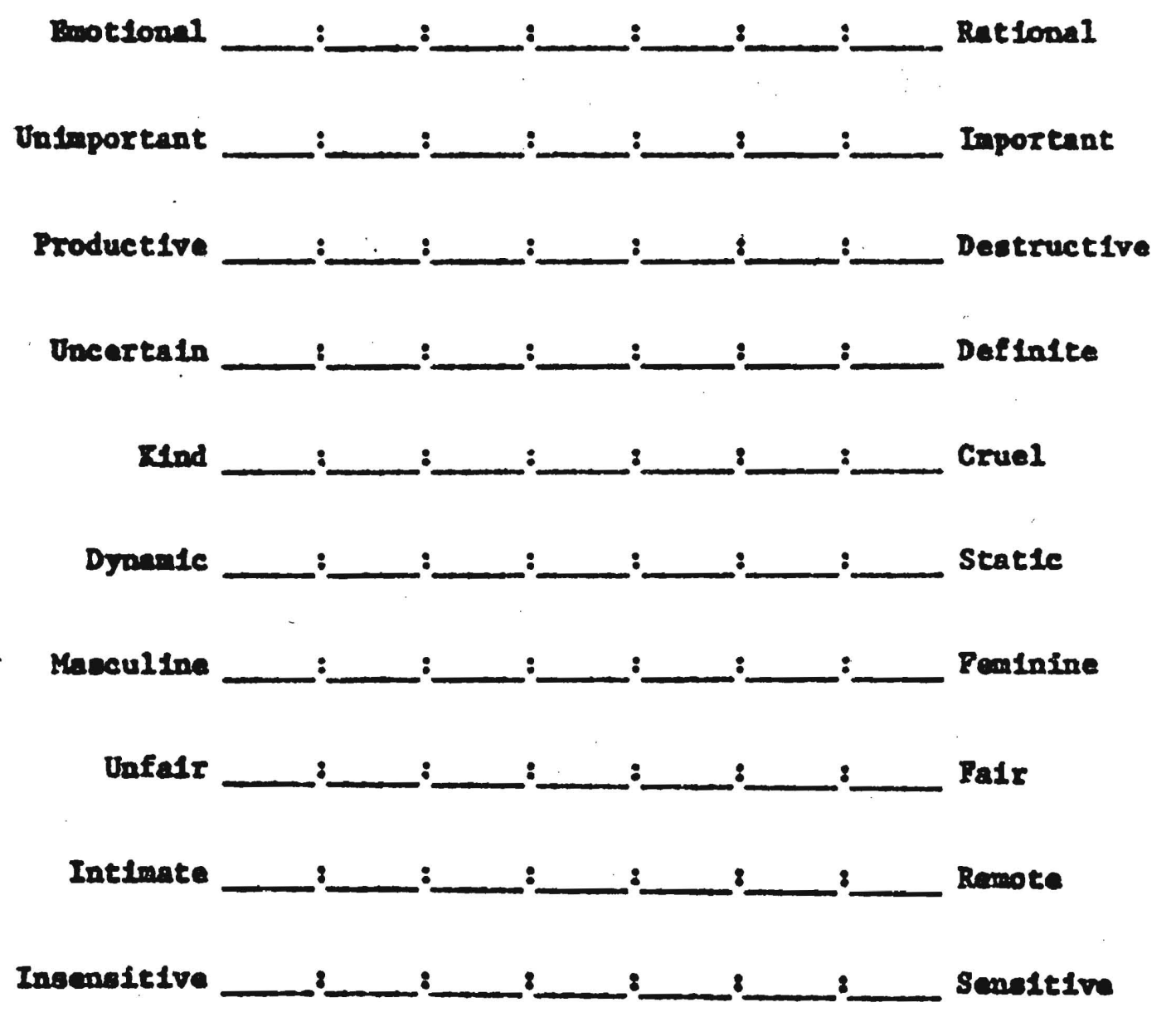


Enotiona1

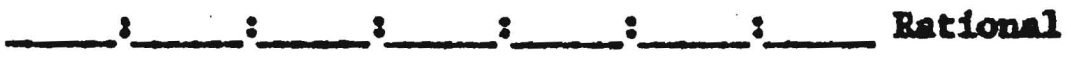

Vutiportant

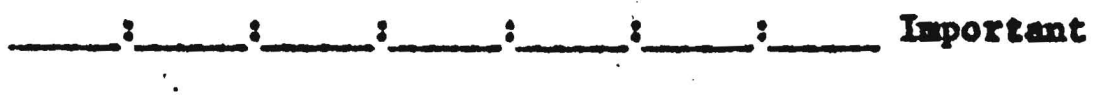

Productive

$+$
: $-$

: Deetruct1v Dncertain ${ }_{-}^{2}$ :Defindte

rind

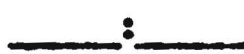
8

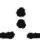
$-$ 8 Cruel Dynamic ${ }^{8}+{ }^{2}$ :: Static

Masculina 8 : 8 Yeminine

Dnfats

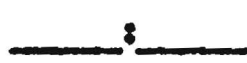
8 $-$ $\therefore$ : Padr

Intimate ${ }^{2}$ : : 8 : Remote

Insensite 8 $-$ 8 $-8$ Sensitive 


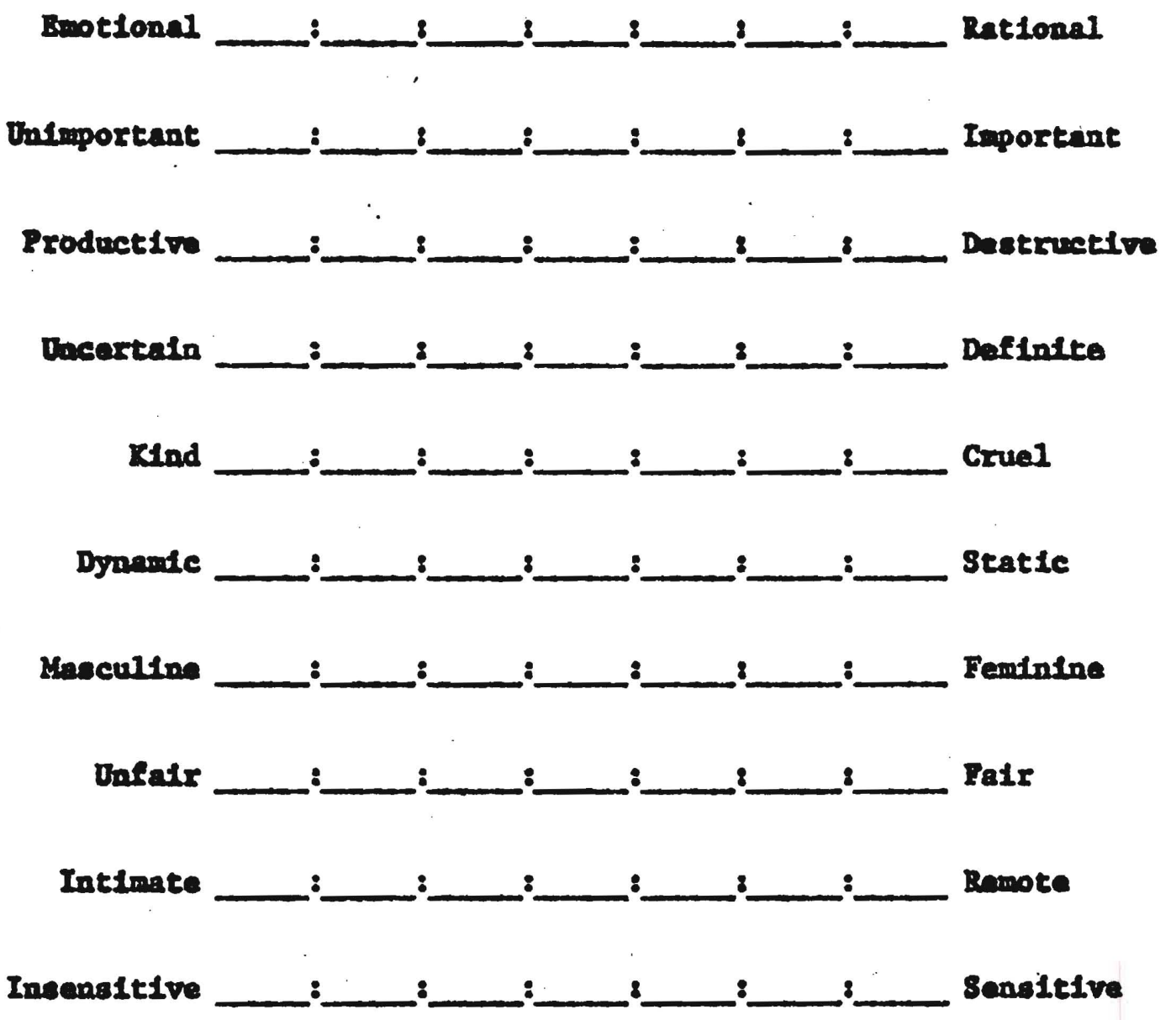




\section{CASERORK}

Bmotional 8

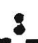
: 8 8 Rationel

Uninportant : : : : Important

Productive $:$ : : : : Destructive

Uncertain $\therefore$ $:$ Defint ve Kind : $-$ 8 : Cruel Dynamic : $-$ : : : static Masculine : $-$ $-$ : : : Feminine

Unfalr 2 : : : : Pair

Intinate : $-$ : : : Ramote

Insensitive : _______ : :: Sensitive 